\title{
Effect of different strontium precursors on the growth process and optical properties of $\mathrm{SrWO}_{4}$ microcrystals
}

\author{
J. C. Sczancoski ${ }^{1}$ W. Avansi ${ }^{2}$ - M. G. S. Costa ${ }^{3}$ M. Siu Li ${ }^{4}$ V. R. Mastelaro ${ }^{4}$ • \\ R. S. Santos ${ }^{5}$ E. Longo ${ }^{1}$ L. S. Cavalcante ${ }^{5}$
}

Received: 31 May 2015/Accepted: 22 August 2015/Published online: 3 September 2015

(C) Springer Science+Business Media New York 2015

\begin{abstract}
In this paper, an experimental study was performed on the effect induced by different strontium precursors in the growth processes and optical properties of strontium tungstate $\left(\mathrm{SrWO}_{4}\right)$ microcrystals synthesized by the co-precipitation method. The structural behavior was analyzed by means of X-ray diffractions, Rietveld refinements, Fourier transform (FT)-Raman, and FT-infrared spectroscopies. X-ray absorption near-edge structure spectra performed at the $\mathrm{W}-\mathrm{L}_{1}$ and $\mathrm{L}_{3}$ edges revealed the first coordination shell around the tungsten atoms is composed of four oxygens, i.e., existence of tetrahedral $\left[\mathrm{WO}_{4}\right]$ clusters inside the $\mathrm{SrWO}_{4}$ structure. Field emission scanning electron microscopy (FE-SEM) images showed the presence of pitch and longleaf pine cone-like $\mathrm{SrWO}_{4}$ microcrystals for most of the strontium precursors employed in the synthesis. Based on these FE-SEM images, a hypothetical crystal growth mechanism was proposed to explain the origin of these microcrystals. The optical properties were investigated by ultraviolet-visible spectroscopy and photoluminescence (PL) measurements at room temperature. The different
\end{abstract}

L. S. Cavalcante

laeciosc@bol.com.br

1 CDMF-Universidade Estadual Paulista, P.O. Box 355, Araraquara, SP 14801-907, Brazil

2 DF-UFSCar-Universidade Federal de São Carlos, P.O. Box 676, São Carlos, SP 13565-905, Brazil

3 Instituto Federal do Maranhão, Química, São Luís, MA 65025-001, Brazil

4 IFSC-Instituto de Física de São Carlos, São Carlos, SP 13560-250, Brazil

5 PPGQ-GERATEC-Universidade Estadual do Piauí, João Cabral, N. 2231, P.O. Box 381, Teresina, PI 64002-150, Brazil optical band gap values found for this material, depending on the type of strontium precursor, were correlated with the existence of intermediary energy levels within the forbidden region. Finally, PL profiles were associated to the degree of distortions in tetrahedral $\left[\mathrm{WO}_{4}\right]$ clusters.

\section{Introduction}

Strontium tungstate $\left(\mathrm{SrWO}_{4}\right)$ is an important material belonging to the scheelite class with excellent optical properties, especially for technological applications in solidstate lasers and stimulated Raman scattering [1, 2]. Basically, this tungstate has attracted the attention of the scientific community and technological areas because of its interesting physicochemical properties, mainly including blue-green phosphors [3], photocatalytic activity for degradation of organic dyes [4, 5], cathodoluminescence [6], thermal expansion $[7,8]$, luminescence $[9,10]$, and so on.

Over the last few years, pure and doped $\mathrm{SrWO}_{4}$ phase has been normally formed by solid-state reaction [11, 12], Czochralski crystal growth [13, 14], and flux evaporation [15]. These preparation methods usually require complex experimental procedures, sophisticated equipments, and rigorous synthesis conditions. Also, there is the probability of formation of deleterious phases, polydisperse particle size distribution, and uncontrolled morphology. Thus, new synthesis methods as electrochemical [16], molten salt [17], sonochemical [18], mechanically assisted solution reaction [19], chemical solution [20], pulsed laser [21], microemulsion [22], solvothermal-mediated microemulsion [23], hydrothermal [24], microwave irradiation [25], and microwave-hydrothermal [26] have been developed with the intention of minimizing these drawbacks. 
In materials science, there is a particular interest in the development of simple synthetic routes with efficient control on the particle shapes and sizes at micro/nanoscale [27]. For example, Thongtem et al. [28] reported the synthesis of $\mathrm{SrWO}_{4}$ nanoparticles using a microwave-assisted solvothermal route. In this study, these researchers analyzed the influence of $\mathrm{pH}$ condition, microwave power, and synthesis times in the formation of these nanoparticles.

In recent years, several researchers have employed $\mathrm{SrWO}_{4}$ crystals as host matrix for the incorporation of trivalent rare earths $\left(\mathrm{Eu}^{3+}, \mathrm{Er}^{3+}, \mathrm{Yb}^{3+}\right.$, and $\left.\mathrm{Tb}^{3+}\right)$ [29] in order to apply in light emission diodes, anode material for lithium-ion batteries [30], and catalyst to removal of toxic metal lead (II) from water [31]. On the other hand, scientific studies on the formation of $\mathrm{SrWO}_{4}$ microcrystals by the co-precipitation method with different strontium precursor salts have not found in the literature.

Therefore, in this paper was analyzed the effect of different strontium precursors on the growth processes and optical properties of $\mathrm{SrWO}_{4}$ microcrystals synthesized by the co-precipitation method at room temperature. These microcrystals were characterized by X-ray diffraction (XRD), Rietveld refinement, X-ray absorption near-edge structure (XANES), Fourier transform Raman (FT-Raman), Fourier transform infrared (FT-IR), ultraviolet-visible (UV-Vis) absorption spectroscopy, photoluminescence (PL) measurements, and field emission scanning electron microscopy (FE-SEM). A plausible growth mechanism for the formation of $\mathrm{SrWO}_{4}$ microcrystals was proposed. Finally, PL properties were analyzed in terms of distortions in $\left[\mathrm{WO}_{4}\right]$ clusters, according with effect induced by the strontium precursor in the synthesis of $\mathrm{SrWO}_{4}$ microcrystals.

\section{Experimental details}

\section{Synthesis of $\mathrm{SrWO}_{4}$ microcrystals}

$\mathrm{SrWO}_{4}$ microcrystals were synthesized according to the following experimental procedure: $5 \times 10^{-3}$ mols of tungstic acid $\left[\mathrm{H}_{2} \mathrm{WO}_{4}\right]\left(99 \%\right.$ purity, Aldrich), $5 \times 10^{-3}$ mols of different strontium salts: strontium acetate $\left[\mathrm{Sr}\left(\mathrm{CH}_{3} \mathrm{CO}_{2}\right)_{2}\right](99.5 \%$ purity, Aldrich), strontium nitrate $\left[\mathrm{Sr}\left(\mathrm{NO}_{3}\right)\right]_{2}(99.5 \%$ purity, Aldrich), and strontium chloride hexahydrate $\left[\mathrm{SrCl}_{2} \cdot 6 \mathrm{H}_{2} \mathrm{O}\right](99.5 \%$ purity, Aldrich) were dissolved in $100 \mathrm{~mL}$ of deionized water. In the precipitation reaction, $\mathrm{Sr}^{2+}$ cations are electron pair acceptors (Lewis acid), while the $\mathrm{WO}_{4}^{2-}$ anions are electron pair donors (Lewis base). The reaction between these two species in solution at room temperature with different strontium salts resulted in the formation of $\mathrm{SrWO}_{4}$ microcrystals, as shown in following equations: $(1,2)$ strontium acetate, $(3,4)$ strontium nitrate, and $(5,6)$ strontium chloride hexahydrate.

$$
\begin{aligned}
& \mathrm{H}_{2} \mathrm{WO}_{2(\mathrm{~s})}+\mathrm{Sr}\left(\mathrm{CH}_{3} \mathrm{CO}_{2}\right)_{2(\mathrm{~s})} \stackrel{\mathrm{H}_{2} \mathrm{O}}{\longrightarrow} \mathrm{Sr}_{(\mathrm{aq})}^{2+}+\mathrm{WO}_{4(\mathrm{aq})}^{2-}+2 \mathrm{H}_{(\mathrm{aq})}^{+} \\
& \quad+2 \mathrm{CH}_{3} \mathrm{CO}_{2(\mathrm{aq})}^{-}
\end{aligned}
$$

$\mathrm{Sr}_{(\mathrm{aq})}^{2+}+\mathrm{WO}_{4(\mathrm{aq})}^{2-}+2 \mathrm{H}_{(\mathrm{aq})}^{+}+2 \mathrm{CH}_{3} \mathrm{CO}_{2(\mathrm{aq})}^{-}$

$\rightarrow \mathrm{SrWO}_{4(\mathrm{~s})}+2 \mathrm{H}_{(\mathrm{aq})}^{+}+2 \mathrm{CH}_{3} \mathrm{CO}_{2(\mathrm{aq})}^{-}$

$\mathrm{H}_{2} \mathrm{WO}_{2(\mathrm{~s})}+\mathrm{Sr}\left(\mathrm{NO}_{3}\right)_{2(\mathrm{~s})} \stackrel{\mathrm{H}_{2} \mathrm{O}}{\longrightarrow} \mathrm{Sr}_{(\mathrm{aq})}^{2+}+\mathrm{WO}_{4(\mathrm{aq})}^{2-}+2 \mathrm{H}_{(\mathrm{aq})}^{+}$

$$
+2 \mathrm{NO}_{3(\mathrm{aq})}^{-}
$$

$$
\begin{aligned}
& \mathrm{Sr}_{(\mathrm{aq})}^{2+}+\mathrm{WO}_{4(\mathrm{aq})}^{2-}+2 \mathrm{H}_{(\mathrm{aq})}^{+}+2 \mathrm{NO}_{3(\mathrm{aq})}^{-} \\
& \quad \rightarrow \mathrm{SrWO}_{4(\mathrm{~s})}+2 \mathrm{H}_{(\mathrm{aq})}^{+}+2 \mathrm{NO}_{3(\mathrm{aq})}^{-}
\end{aligned}
$$

$$
\begin{aligned}
& \mathrm{H}_{2} \mathrm{WO}_{2(\mathrm{~s})}+\mathrm{SrCl}_{2} \cdot 6 \mathrm{H}_{2} \mathrm{O}_{(\mathrm{s})} \stackrel{\mathrm{H}_{2} \mathrm{O}}{\longrightarrow} \mathrm{Sr}_{(\mathrm{aq})}^{2+}+\mathrm{WO}_{4(\mathrm{aq})}^{2-}+2 \mathrm{H}_{(\mathrm{aq})}^{+} \\
& \quad+2 \mathrm{Cl}_{(\mathrm{aq})}^{-}+6 \mathrm{H}_{2} \mathrm{O}
\end{aligned}
$$

$\mathrm{Sr}_{(\mathrm{aq})}^{2+}+\mathrm{WO}_{4(\mathrm{aq})}^{2-}+2 \mathrm{H}_{(\mathrm{aq})}^{+}+2 \mathrm{Cl}_{(\mathrm{aq})}^{-}+6 \mathrm{H}_{2} \mathrm{O}$

$\rightarrow \mathrm{SrWO}_{4(\mathrm{~s})}+2 \mathrm{H}_{(\mathrm{aq})}^{+}+2 \mathrm{Cl}_{(\mathrm{aq})}^{-}+6 \mathrm{H}_{2} \mathrm{O}$.

In order to increase the ionization rate of $\mathrm{H}_{2} \mathrm{WO}_{4}$, the $\mathrm{pH}$ solution was adjusted up to 10 by the addition of $6 \mathrm{~mL}$ of ammonium hydroxide $\left[\mathrm{NH}_{4} \mathrm{OH}\right]\left(30 \%\right.$ in $\mathrm{NH}_{3}$, Mallinckrodt). Thereafter, these aqueous solutions were stirred for $30 \mathrm{~min}$ at room temperature. After the co-precipitation reaction is completed, these systems were washed and centrifuged several times with deionized water to neutralize the $\mathrm{pH}(\approx 7)$. Finally, the collected precipitates were dried in a lab oven at $60{ }^{\circ} \mathrm{C}$ for some hours.

\section{Characterizations of $\mathrm{SrWO}_{4}$ microcrystals}

The synthesized microcrystals were structurally characterized by X-ray diffraction (XRD) using a DMax/2500PC diffractometer (Rigaku, Japan). XRD patterns were obtained with $\mathrm{Cu}-\mathrm{K} \alpha$ radiation in the $2 \theta$ range from $10^{\circ}$ to $90^{\circ}$, using a scanning speed of $2 \% \mathrm{~min}$. For Rietveld routines were adopted a $2 \theta$ range from $10^{\circ}$ to $110^{\circ}$ with a scanning speed of $0.02 \%$ s. The electronic and local atomic structures around tungsten (W) atoms were checked by $\mathrm{X}$-ray absorption near-edge structure (XANES). $\mathrm{W} \mathrm{L}_{1,3^{-}}$ edge XANES spectra were measured at the National Synchrotron Light Laboratory (LNLS) in Brazil, using the D04BXAFS1 beam line. XANES data were collected in transmission mode at room temperature with the samples deposited on polymeric membranes. These spectra were recorded for each sample using an energy step of $1.0 \mathrm{eV}$, before and after the edge, and $0.7 \mathrm{eV}$ near the edge for $\mathrm{W}-\mathrm{L}_{1}$ and $\mathrm{L}_{3}$ edge, respectively. The tungsten oxide $\left(\mathrm{WO}_{3}\right)$ 
( $\geq 99 \%$ ) purchase from Aldrich was employed as reference compound in these measurements. FT-Raman spectra were recorded by means of a RFS100 spectrophotometer (Bruker, Germany) equipped with a Nd:YAG laser ( $\lambda=1064 \mathrm{~nm}$ ), operating at $100 \mathrm{~mW}$. FT-IR spectra were performed in the range from 50 to $1200 \mathrm{~cm}^{-1}$, using an Equinox 55 spectrometer (Bruker, Germany) in transmittance mode. The morphologies were analyzed using a Supra 35-VP FE-SEM (Carl Zeiss, Germany) operated at $15 \mathrm{kV}$. UV-Vis absorption were taken using a Cary 5G spectrophotometer (Varian, USA) in diffuse reflection mode. PL spectra were obtained with a Monospec 27 monochromator (Thermal Jarrel Ash, USA) coupled to a R446 photomultiplier (Hamamatsu Photonics, Japan). A krypton ion laser (Coherent Innova 200K, USA) $(\lambda=350 \mathrm{~nm})$ was used as excitation source. The incident laser beam power on the samples was kept at $14 \mathrm{~mW}$. UV$\mathrm{Vis}$ and PL measurements were taken three times for each sample to ensure the reliability of the results. In our study, all experimental measurements were performed at room temperature.

\section{Results and discussion}

\section{X-ray diffraction and Rietveld refinement analyses}

Figure 1 shows the XRD patterns of $\mathrm{SrWO}_{4}$ microcrystals co-precipitated with different strontium precursors.

The diffraction peaks can be used to evaluate the structural order at long range or periodicity of the material. In our case, the intense and sharp peaks of $\mathrm{SrWO}_{4}$ crystals co-precipitated at room temperature indicate a good

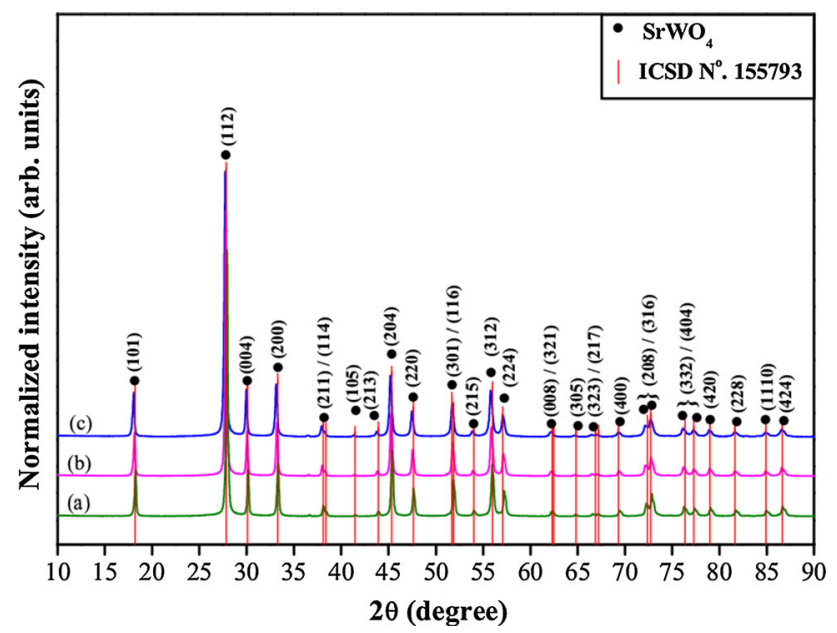

Fig. 1 XRD patterns of $\mathrm{SrWO}_{4}$ microcrystals synthesized with $a \mathrm{SrNO}_{3}, b \mathrm{SrCl}_{2} \cdot 6 \mathrm{H}_{2} \mathrm{O}$, and $c \operatorname{Sr}\left(\mathrm{CH}_{3} \mathrm{CO}_{2}\right)_{2}$. The vertical lines indicate the respective positions and intensities found in ICSD card no. 155793 crystallinity or periodicity at long range [32]. In Fig. 1a-c, XRD patterns provided the $\mathrm{SrWO}_{4}$ microcrystals synthesized with $\mathrm{Sr}\left(\mathrm{NO}_{3}\right)_{2}, \mathrm{SrCl}_{2} \cdot 6 \mathrm{H}_{2} \mathrm{O}$, and $\mathrm{Sr}\left(\mathrm{CH}_{3} \mathrm{CO}_{2}\right)_{2}$ precursors have single phase, which were perfectly assigned to the scheelite-type tetragonal structure with space group $I 4_{1} / a$ (ICSD card no. 155793) [33].

Figure $2 \mathrm{a}-\mathrm{c}$ illustrates the Rietveld refinement plots of $\mathrm{SrWO}_{4}$ microcrystals co-precipitated with different strontium precursors.

The Rietveld refinement is a method in which the profile intensities obtained from step-scanning measurements of solid samples allow to estimate an approximate structural model for the real structure [34]. In our study, the Rietveld refinements were performed using the general structure analysis system (GSAS) software package with the EXPGUI graphical interface [35]. The refined parameters were scale factor, background, shift lattice constants, profile half-width parameters $(u, v, w)$, isotropic thermal parameters, strain anisotropy factor, atomic functional positions, bond lengths, and bond angles. The background was corrected using the Chebyshev polynomials of the first kind [36]. The diffraction peak profiles were better fitted by the Thompson-Cox-Hastings pseudo-Voigt (pVTCH) function [37] and asymmetry function described by Finger et al. [38]. The strain anisotropy was corrected by the phenomenological model described by Stephens [39]. The theoretical diffraction pattern was taken from ICSD card no. 155793 [33], which is based on the $\mathrm{SrWO}_{4}$ phase with scheelite-type tetragonal structure and space group $I 4_{1} / a$. The Rietveld refinements of $\mathrm{SrWO}_{4}$ microcrystals are shown in Fig. 2a-c, which are in good agreement with XRD results illustrated in Fig. 1. The obtained results from Rietveld refinements are listed in Table 1.

In this table, the fitting parameters $\left(R_{\mathrm{wp}}, R_{\mathrm{p}}, R_{\mathrm{Bragg}}, \chi^{2}\right.$, and $S$ ) indicate a good agreement between refined and observed XRD patterns for $\mathrm{SrWO}_{4}$ phase. The lattice parameter values, unit cell volume, atomic positions, and bond angles confirmed the $\mathrm{SrWO}_{4}$ phase has a tetragonal structure. All refinements reported in our study are in good agreement with those previously published [40, 41].

\section{Structural representation of $\mathrm{SrWO}_{4}$ crystals}

Figure 3 illustrates the $\mathrm{SrWO}_{4}$ structure modeled through the Diamond Crystal and Molecular Structure Visualization software [42], using the lattice parameters and atomic positions obtained from Rietveld refinements as input data.

$\mathrm{SrWO}_{4}$ crystallizes in a tetragonal structure with space group $I 4_{1} / a$ [43]. Chen et al. [44] described the tetragonal $\mathrm{SrWO}_{4}$ structure constituted of four molecules per unit cell $(Z=4)$. Jia et al. [45] explained the A-sites related to strontium (Sr) atoms present point symmetry $\left(S_{4}\right)$. Thus, $\mathrm{SrWO}_{4}$ structure exhibits the $\mathrm{Sr}$ atoms bonded to eight 

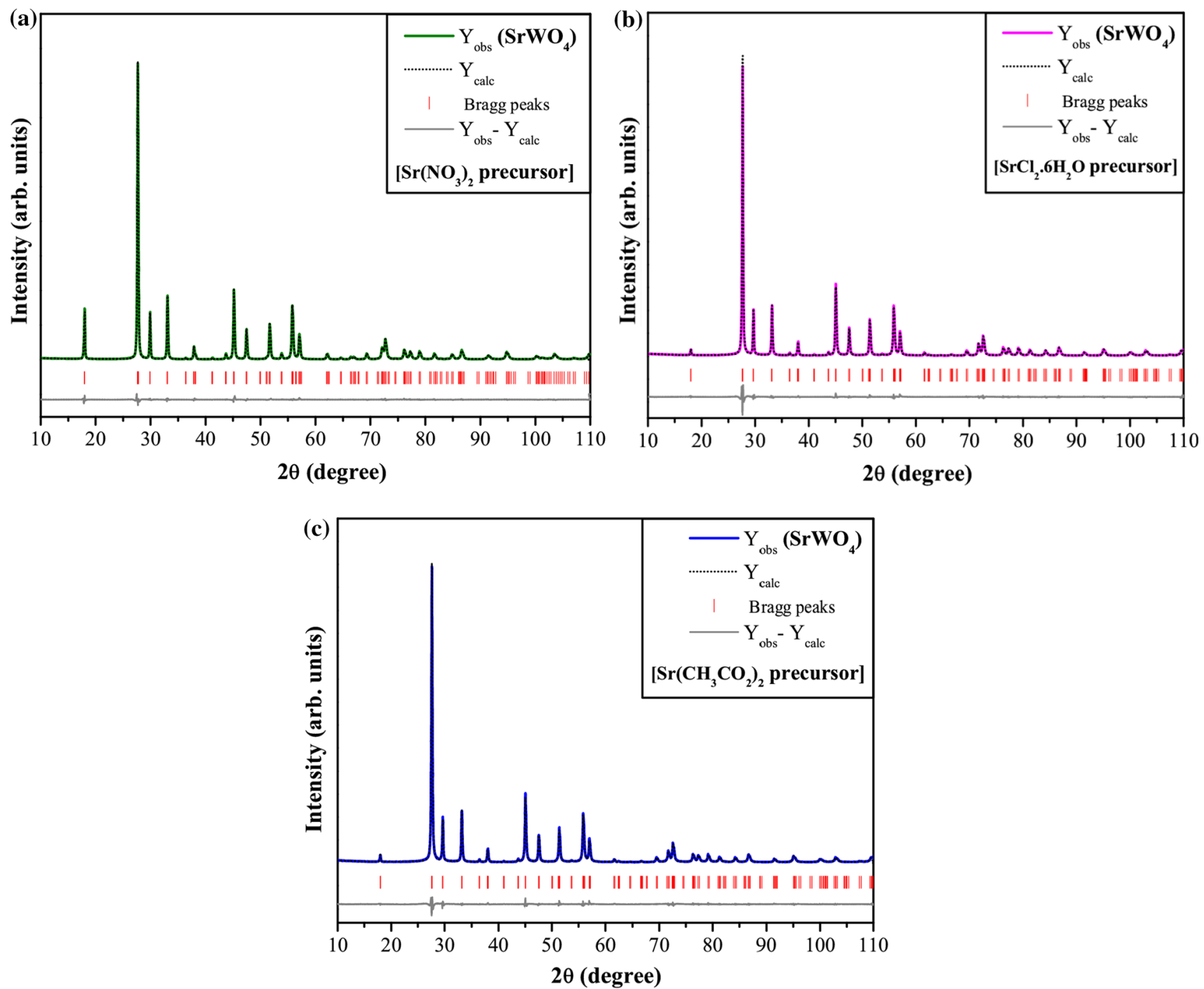

Fig. 2 Rietveld refinement plots of $\mathrm{SrWO}_{4}$ microcrystals synthesized with the precursors salts: a $\mathrm{SrNO}_{3}, \mathbf{b} \mathrm{SrCl}_{2} \cdot 6 \mathrm{H}_{2} \mathrm{O}$, and $\mathbf{c} \mathrm{Sr}\left(\mathrm{CH}_{3} \mathrm{CO}_{2}\right)_{2}$

oxygens ( $\left[\mathrm{SrO}_{8}\right]$ clusters), forming snub-disphenoid polyhedra ( 8 vertices, 12 faces, and 18 edges) and point-group symmetry $\left(\mathrm{D}_{2 d}\right)$. On the other hand, tungsten $(\mathrm{W})$ atoms are coordinated to four oxygens ([ $\left.\mathrm{WO}_{4}\right]$ clusters) with tetrahedral geometry (4 vertices, 4 faces, and 6 edges) and point-group symmetry $\left(T_{d}\right)$. The tetrahedral $\left[\mathrm{WO}_{4}\right]$ clusters are slightly distorted inside the structure, as consequence of $\mathrm{O}-\mathrm{W}-\mathrm{O}$ bond angles $\left(\alpha=106.1^{\circ}\right.$ and $\left.\beta=116.43^{\circ}\right)$ as shown in Fig. 3.

\section{XANES spectroscopy analyses}

Figure 4a shows $\mathrm{W} \mathrm{L}_{1}$-edge XANES spectra, (b) area of the $\mathrm{W} \mathrm{L}_{1}$-edge peak, and (c) $\mathrm{W} \mathrm{L}_{3}$-edge XANES spectra of $\mathrm{SrWO}_{4}$ microcrystals co-precipitated with different strontium precursors, respectively.
According to the literature [46-48], $\mathrm{W} \mathrm{L}_{1}$-edge XANES spectrum is a powerful tool to provide any information on the coordination environment (tetrahedral, square-based pyramid, octahedral, etc.), oxidation state, and local geometry of tungsten atoms. A closer examination in Fig. 4a revealed the XANES spectra of $\mathrm{SrWO}_{4}$ microcrystals present intense and narrow $\mathrm{W}-\mathrm{L}_{1}$ pre-edge absorption peaks $(\mathbf{X})$ at around $12108 \mathrm{eV}$. This particular behavior is related to the existence of distorted tetrahedral [ $\left.\mathrm{WO}_{4}\right]$ clusters (Inset in Fig. 4a) [49]. On the other hand, the spectrum of $\mathrm{WO}_{3}$ (standard sample) exhibited a slight shoulder in this same energy region. Kuzmin and Purans [50] reported the $\mathrm{W}-\mathrm{L}_{1}$ pre-edge absorption peak $(\mathbf{X})$ is originated by the electronic transitions from $2 s(\mathrm{~W})$ to $5 d(\mathrm{~W})+2 p(\mathrm{O})$ orbitals. In other published studies [51], these authors explained that these electronic transitions are 
Table 1 Lattice parameters, unit cell volume, site occupancy, and statistical parameters obtained from Rietveld refinements of $\mathrm{SrWO}_{4}$ microcrystals synthesized with different strontium precursors

\begin{tabular}{llllll}
\hline & Wyckoff & Site & $x$ & $y$ & $z$ \\
\hline $\boldsymbol{\nabla}$ Atoms & & & & & \\
Strontium & $4 b$ & -4 & 0 & 0.25 & 0.625 \\
Tungsten & $4 a$ & -4 & 0 & 0.25 & 0.125 \\
Oxygen & $16 f$ & 1 & 0.2395 & 0.1062 & 0.0453 \\
• Atoms & & & & & \\
Strontium & $4 b$ & -4 & 0 & 0.25 & 0.625 \\
Tungsten & $4 a$ & -4 & 0 & 0.25 & 0.125 \\
Oxygen & $16 f$ & 1 & 0.2465 & 0.1106 & 0.0455 \\
A Atoms & & & & & \\
Strontium & $4 b$ & -4 & 0 & 0.25 & 0.625 \\
Tungsten & $4 a$ & -4 & 0 & 0.25 & 0.125 \\
Oxygen & $16 f$ & 1 & 0.2497 & 0.0925 & 0.0421 \\
\hline
\end{tabular}

$R_{\mathrm{wp}}=6.16 \%, R_{\mathrm{p}}=4.54 \%, R_{\mathrm{Bragg}}=3.28 \%, \chi^{2}=3.9, S=1.975$, $\alpha=\beta=\gamma=90^{\circ} \quad(a=b=5.4277(6) \quad \AA \quad$ e $c=11.9727(5) \quad \AA)$. $R_{\mathrm{wp}}=7.20 \%, R_{\mathrm{p}}=5.37 \%, R_{\mathrm{Bragg}}=2.78 \%, \chi^{2}=5.0, S=2.236$, $\alpha=\beta=\gamma=90^{\circ} \quad(a=b=5.4281(2) \quad \AA$ e $c=11.9762(2) \AA)$. $R_{\mathrm{wp}}=6.95 \%, R_{\mathrm{p}}=5.29 \%, R_{\mathrm{Bragg}}=1.99 \%, \chi^{2}=4.0, S=2.0$, $\alpha=\beta=\gamma=90^{\circ}(a=b=5.4276(3) \AA$ e $c=11.9761(4) \AA)$. $\nabla$ $\mathrm{SrWO}_{4}$ with $\mathrm{Sr}\left(\mathrm{CH}_{3} \mathrm{CO}_{2}\right)_{2}$ precursor, * $\mathrm{SrWO}_{4}$ with $\mathrm{SrCl}_{2} \cdot 6 \mathrm{H}_{2} \mathrm{O}$ precursor, and \& $\mathrm{SrWO}_{4}$ with $\mathrm{Sr}\left(\mathrm{NO}_{3}\right)_{2}$ precursor

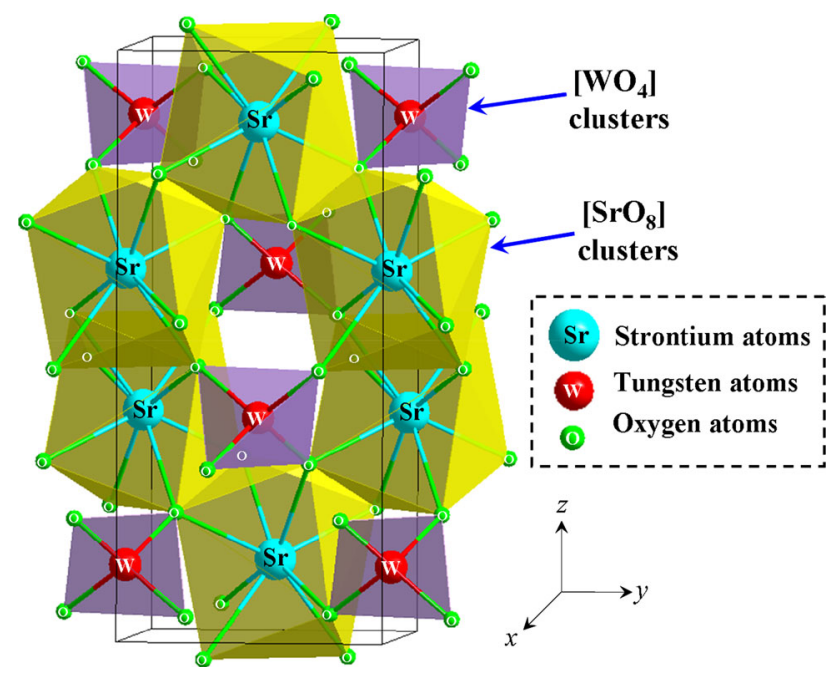

Fig. 3 Schematic representation of tetragonal $\mathrm{SrWO}_{4}$ structure

all dipole forbidden in undistorted octahedral $\left[\mathrm{WO}_{6}\right]$ clusters (inversion center) and allowed in both distorted octahedral $\left[\mathrm{WO}_{6}\right]$ and tetrahedral $\left[\mathrm{WO}_{4}\right]$ clusters. Moreover, the intensity of the $\mathrm{W}-\mathrm{L}_{1}$ pre-edge absorption peak $(\mathbf{X})$ is very sensitive and dependent on the degree of distortion in octahedral $\left[\mathrm{WO}_{6}\right]$ clusters relate to $5 d(\mathrm{~W})+2 p(\mathrm{O})$ orbitals [52]. We calculate the area of the $\mathrm{W}-\mathrm{L}_{1}$ pre-edge peak to evaluate the effect of strontium

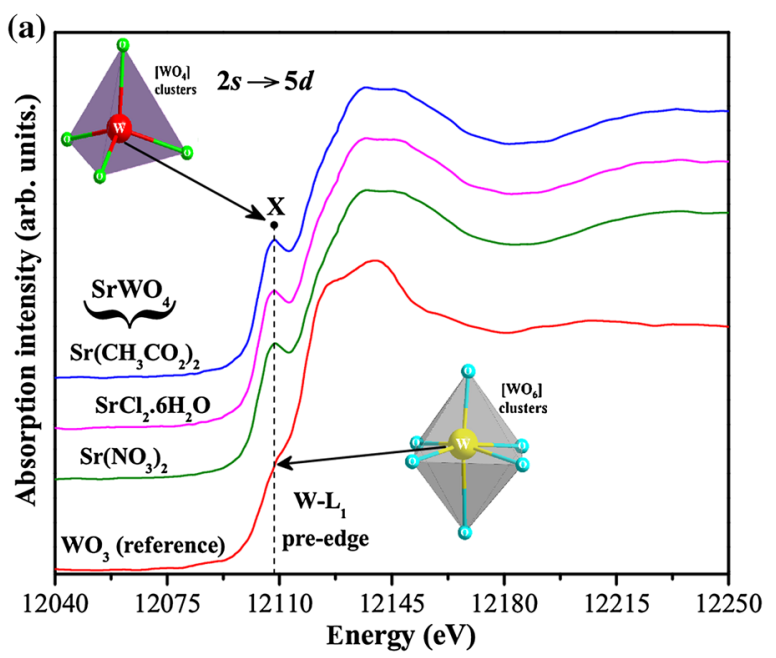

(b)

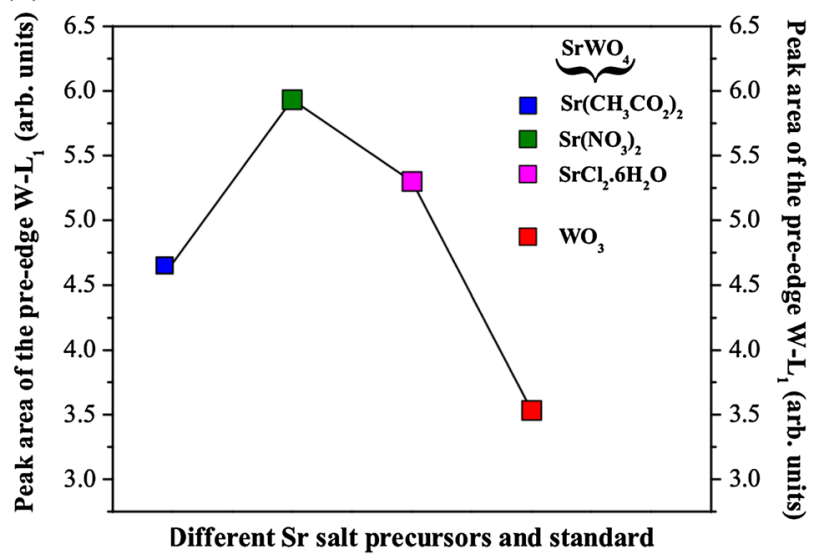

(c)

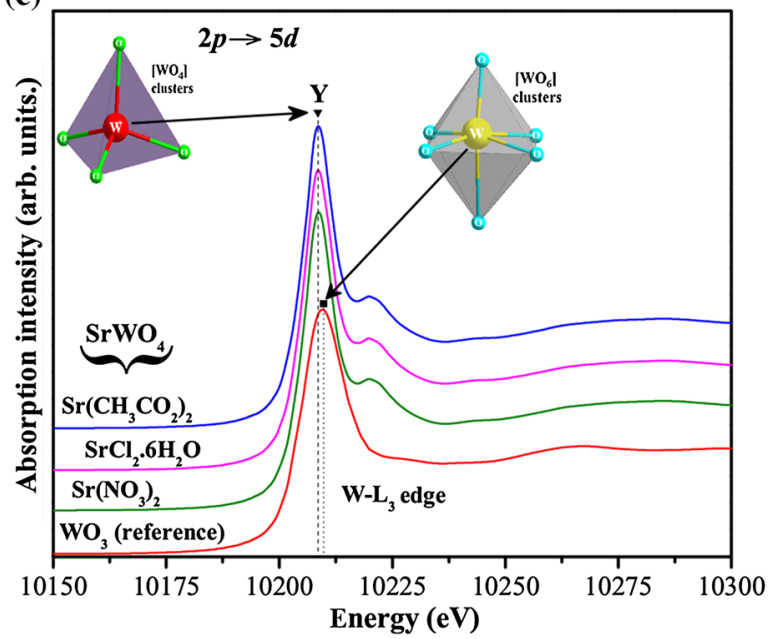

Fig. 4 XANES spectra of $\mathrm{SrWO}_{4}$ microcrystals at the a W-L $\mathrm{L}_{1}$ preedge, $\mathbf{b}$ area of the $\mathrm{W}-\mathrm{L}_{1}$ pre-edge peaks, and $\mathbf{c}$ XANES spectra at the (a) W-L $\mathrm{L}_{3}$ edge. $\mathrm{WO}_{3}$ with monoclinic structure (Sigma-Aldrich $99.9 \%$ purity) was used as standard sample

precursors in the degree of distortion of $\left[\mathrm{WO}_{4}\right]$ clusters (order-disorder at short range) found in $\mathrm{SrWO}_{4}$ microcrystals (Fig. 4b). For this purpose was employed the 
peakFit program (4.12 version), using the Voigt function [53]. According to the literature [54], the high area of the $\mathrm{W}-\mathrm{L}_{1}$ pre-edge peak of $\mathrm{SrWO}_{4}$ microcrystals synthesized with $\mathrm{SrNO}_{3}$ is associated to the strong interaction between tungsten and oxygen atoms. $\mathrm{WO}_{3}$ used as standard sample exhibited a low value for the area of $\mathrm{W}-\mathrm{L}_{1}$ pre-edge peak; however, this behavior was ascribed to change of coordination in octahedral $\left[\mathrm{WO}_{6}\right]$ clusters, as a consequence of a split into $e_{g}$ and $t_{2 g}$ orbitals by the ligand field theory. However, $\mathrm{SrWO}_{4}$ microcrystals have only tetrahedral $\left[\mathrm{WO}_{4}\right]$ clusters, which present a split into $t_{2}$ and $e$ orbitals.

XANES spectra at the $\mathrm{W} \mathrm{L}_{3}$-edge of $\mathrm{SrWO}_{4}$ microcrystals are illustrated in Fig. 4c. Over again, $\mathrm{WO}_{3}$ was employed as reference sample in these spectra. The preedge peak was located at around $10208 \mathrm{eV}$ for $\mathrm{SrWO}_{4}$ microcrystals and approximately $10210 \mathrm{eV}$ for $\mathrm{WO}_{3}$. $\mathrm{SrWO}_{4}$ microcrystals synthesized with different strontium precursors have their $\mathrm{W}$ atoms bonded to four oxygens in a tetrahedral environment $\left(\left[\mathrm{WO}_{4}\right]\right.$ clusters), while the $\mathrm{WO}_{3}$ has $\mathrm{W}$ atoms bonded to six oxygens in a distorted octahedral configuration ([ $\left.\mathrm{WO}_{6}\right]$ clusters). As a response to these differences in the coordination number, a slight shift in the respective positions of edge peak $(\mathbf{Y})$ was detected between these samples in XANES spectra $(\approx 10208 \mathrm{eV}$ for $\mathrm{SrWO}_{4}$ microcrystals $(\boldsymbol{\nabla})$ and $\approx 10210 \mathrm{eV}$ for $\mathrm{WO}_{3}$ powder $(\square)$ ). The origin of this pre-edge peak at the $\mathrm{W} \mathrm{L}_{3^{-}}$ edge is ascribed to the permitted dipole transition from $2 p_{3 / 2}(\mathrm{~W})$ level to quasi-bound mixed state $5 d(\mathrm{~W})+$ $2 p(\mathrm{O})$ [55]. XANES spectra in our study of $\mathrm{SrWO}_{4}$ microcrystals are in good agreement with those previously published on tungstates with scheelite-type tetragonal structure [56].

\section{FT-Raman and FT-IR spectroscopies analyses}

According to group theory calculations, $\mathrm{SrWO}_{4}$ microcrystals are able to present 26 different vibration modes (Eq. (7)) [57]:

$$
\begin{aligned}
\Gamma_{[\text {Raman }]+(\text { infrared })=} & {\left[3 A_{g}+5 B_{g}+5 E_{g}\right] } \\
& +\left(5 A_{u}+3 B_{u}+5 E_{u}\right),
\end{aligned}
$$

where $A_{g}, B_{g}$, and $E_{g}$ are Raman-active vibration modes; $A$ and $B$ modes are nondegenerate, while $E$ modes are doubly degenerate. The subscripts $[g]$ and $(u)$ indicate the parity under inversion in centrosymmetric of $\mathrm{SrWO}_{4}$ microcrystals. $A_{u}$ and $E_{u}$ modes correspond to zero frequency of acoustic modes, while the others are optic modes. In addition, $A_{g}, B_{g}$, and $E_{g}$ modes arise from the same motion of $\mathrm{SrWO}_{4}$ microcrystals. Therefore, it is expected 13 zonecenter Raman-active modes for $\mathrm{SrWO}_{4}$ microcrystals, as presented in Eq. (8) [58]:
$\Gamma_{[\text {Raman }]}=3 A_{g}+3 B_{g}+5 E_{g}$.

Degreniers et al. [59] reported the vibrational modes observed in Raman spectra of $\mathrm{SrWO}_{4}$ can be classified into two groups: external and internal modes. The vibrational external modes are related to lattice phonon, which corresponds to the motion of $\left[\mathrm{SrO}_{8}\right]$ clusters and the rigid units. The vibrational internal modes are correspondent to the vibration inside tetrahedron $\left[\mathrm{WO}_{4}\right]$ clusters, considering the center of mass in stationary state. The isolated $\left[\mathrm{WO}_{4}\right]$ clusters have a cubic symmetry point $\left(T_{d}\right)$ and its vibrations are composed of four internal modes $\left(v_{1}\left(A_{1}\right), v_{2}\left(E_{1}\right)\right.$, $\left.v_{3}\left(F_{2}\right)\right)$, and $\left.v_{4}\left(F_{2}\right)\right)$, one free rotation mode $\left(v_{f . r .}\left(F_{1}\right)\right)$ and one translation mode $\left(F_{2}\right)$. On the other hand, the tungsten atoms belonging to tetrahedral $\left[\mathrm{WO}_{4}\right]$ clusters occupy the $4 a$ Wyckoff positions with point symmetry $\left(S_{4}\right)$, while the $\mathrm{O}$ atoms occupy the $16 f$ Wyckoff positions with point symmetry $\left(C_{1}\right)$.

Figure 5 shows the FT-Raman spectra in the range from 50 to $1200 \mathrm{~cm}^{-1}$ of $\mathrm{SrWO}_{4}$ microcrystals co-precipitated with different strontium precursors.

As can be observed in Fig. 5, FT-Raman spectra revealed the presence of twelve Raman-active vibration modes. One $B_{g}$ mode was not detectable because of its low intensity. The literature [56] describes the Raman spectroscopy can be employed as a structural probe to investigate the degree of structural order-disorder at short range in $\mathrm{ABO}_{4}$ materials. Based on this concept, Raman spectra consisting of sharp, intense, and well-defined vibration bands are commonly verified in solids with local structural order. This phenomenon was verified in all $\mathrm{SrWO}_{4}$ microcrystals obtained at room temperature by the

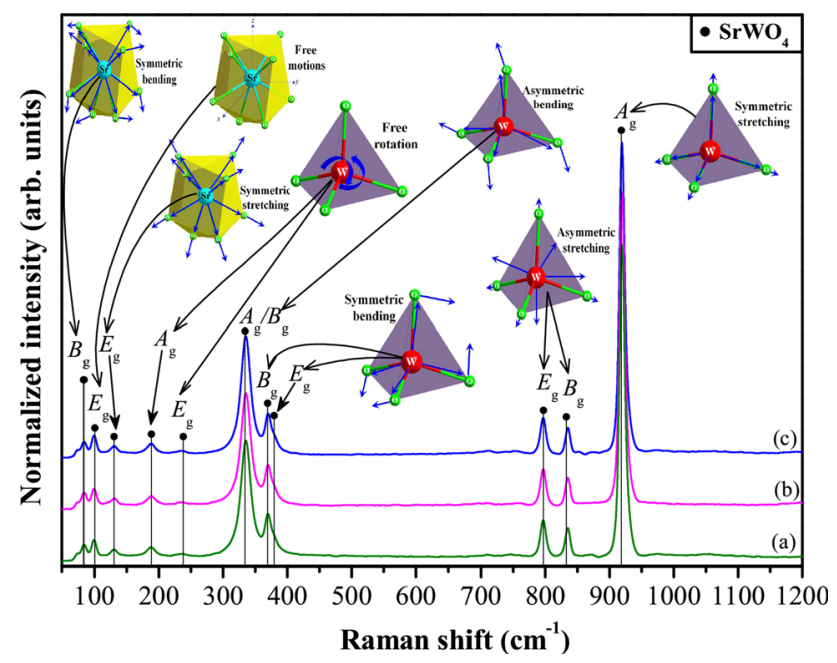

Fig. 5 FT-Raman spectra of $\mathrm{SrWO}_{4}$ microcrystals synthesized with different strontium precursors. Insets show the typical bending and stretching vibrations exhibited by $\mathrm{O}-\mathrm{Sr}-\mathrm{O}$ and $\mathrm{O}-\mathrm{W}-\mathrm{O}$ bonds of $\left[\mathrm{SrO}_{8}\right]$ and $\left[\mathrm{WO}_{4}\right]$ clusters, respectively 
co-precipitation method with $\left[\mathrm{Sr}\left(\mathrm{CH}_{3} \mathrm{CO}_{2}\right)_{2}\right],\left[\mathrm{Sr}\left(\mathrm{NO}_{3}\right)\right]_{2}$, and $\left[\mathrm{SrCl}_{2} \cdot 6 \mathrm{H}_{2} \mathrm{O}\right]$. Our Raman results for $\mathrm{SrWO}_{4}$ microcrystals are in good agreement with those previously published [58, 59]. Insets in Fig. 5a illustrate each assignment to Raman-active external and internal modes of $\mathrm{SrWO}_{4}$ microcrystals. The first Raman-active $B_{g}$ mode $\left(83 \mathrm{~cm}^{-1}\right)$ is related to symmetric bending vibrations of $(\mathrm{O}-\mathrm{Sr}-\mathrm{O})$ bonds in $\left[\mathrm{SrO}_{8}\right]$ clusters, the second Ramanactive $E_{g}$ mode $\left(100 \mathrm{~cm}^{-1}\right)$ is assigned to free motion at ( $x$, $y, z$-axis) of $\left[\mathrm{SrO}_{8}\right]$ clusters, and the third Raman-active $E_{g}$ mode $\left(129 \mathrm{~cm}^{-1}\right)$ is ascribed to symmetric stretching vibrations of $(\leftarrow \mathrm{O} \leftarrow \mathrm{Sr} \rightarrow \mathrm{O} \rightarrow)$ bonds in $\left[\mathrm{SrO}_{8}\right]$ clusters. The fourth and fifth Raman-active $A_{g}$ and $E_{g}$ modes (188 and $236 \mathrm{~cm}^{-1}$ ) are classically identified as free rotation of tetrahedral $\left[\mathrm{WO}_{4}\right]$ clusters. The sixth Raman-active $B_{g}$ mode was not possible to detect it. The seventh and eighth Raman-active $A_{g} / B_{g}$ modes are overlapped $\left(335 \mathrm{~cm}^{-1}\right)$, which are designed to asymmetric bending vibrations of $(\leftarrow \mathrm{O} \leftarrow \mathrm{W} / \mathrm{Sr} \downarrow \mathrm{O} \downarrow)$ bonds in $\left[\mathrm{WO}_{4}\right]$ clusters. The ninth and tenth Raman-active $B_{g}$ and $E_{g}$ modes (370 and $380 \mathrm{~cm}^{-1}$, respectively) are assigned to symmetric bending vibrations of $\left[\mathrm{WO}_{4}\right]$ clusters, and the eleventh and twelfth Raman-active $E_{g}$ and $B_{g}$ modes (796 and $835 \mathrm{~cm}^{-1}$, respectively) are related to asymmetric stretching vibrations of $(\leftarrow \mathrm{O}-\mathrm{W} \rightarrow / \leftarrow \mathrm{O}-\mathrm{W} \rightarrow)$ bonds in $\left[\mathrm{WO}_{4}\right]$ clusters. Finally, the thirteenth Raman-active $A_{\mathrm{g}}$ mode $\left(919 \mathrm{~cm}^{-1}\right)$ is referent to symmetric stretching vibrations of $(\leftarrow \mathrm{O} \leftarrow$ $\mathrm{W} \rightarrow \mathrm{O} \rightarrow$ ) bonds in $\left[\mathrm{WO}_{4}\right]$ clusters. In addition, a comparison was made with the literature $[58,59]$ (Table 2).

In this table, the slight variations in the typical positions of Raman-active vibration modes are caused by distortions or changes in the length $(\mathrm{O}-\mathrm{W}-\mathrm{O}) /(\mathrm{O}-\mathrm{Sr}-\mathrm{O})$ bonds, modifications in the interaction forces involving the $\left[\mathrm{WO}_{4}\right]-\left[\mathrm{SrO}_{8}\right]-\left[\mathrm{WO}_{4}\right]$ clusters, and the presence of structural order-disorder in the lattice, in consequence of the preparation methods and their experimental conditions.

Figure 6a, b shows FT-IR spectra in the range from 395 to $1000 \mathrm{~cm}^{-1}$ and from 1000 to $4000 \mathrm{~cm}^{-1}$ of $\mathrm{SrWO}_{4}$ microcrystals, respectively.

In infrared spectra are expected 13 infrared vibrational modes $\left(5 A_{\mathrm{u}}+3 B_{\mathrm{u}}+5 E_{\mathrm{u}}\right)$ for tungstates. However, $1 A_{u}$ and $1 E_{u}$ are acoustic vibrations, i.e., infrared-inactive modes, while the others $3 B_{u}$ are forbidden infrared modes. Therefore, only 8 infrared-active vibration modes remain, as presented in Eq. (9) [60]:

$\Gamma_{\text {(infrared) }}=4 A_{u}+4 E_{u}$

In our FT-IR spectra illustrated in Fig. 6a, only two of eight IR-active modes were verified. $3 A_{u}$ and $3 E_{u}$ modes may not have been detected due to limitations imposed by the FT-IR equipment. As was previously described, the tungstates with scheelite-type tetragonal structure have eight stretching and/or bending vibrational modes in their
FT-IR spectra. In our spectra were verified no more than two modes $\left(1\left(A_{u}\right)\right.$ and $\left.1\left(E_{u}\right)\right)$, which were identified at specific positions in the spectra (Fig. 6a). The first strong absorption band located at around $417 \mathrm{~cm}^{-1}$ is ascribed to $A_{u}$ mode. The strong and broad absorption band related to $E_{u}$ mode located at $823 / 844 \mathrm{~cm}^{-1}$ was ascribed to $(\leftarrow$ $\mathrm{O} \leftarrow \mathrm{W} \leftarrow \mathrm{O} \leftarrow) /(\rightarrow \mathrm{O} \rightarrow \mathrm{W} \rightarrow \mathrm{O} \rightarrow)$ anti-symmetric stretching vibrations inside the $\left[\mathrm{WO}_{4}\right]$ clusters. In Fig. $6 \mathrm{~b}$ was verified other absorption bands in FT-IR spectra due to the presence of carbon dioxide $\left(\mathrm{CO}_{2}\right)$ and water $\left(\mathrm{H}_{2} \mathrm{O}\right)$ arising from the room atmosphere and humidity. The small band noted at $2500 \mathrm{~cm}^{-1}$ is due to $v(\mathrm{C}=\mathrm{O})$ stretching mode. The broad absorption band at $3400 \mathrm{~cm}^{-1}$ corresponds to $\mathrm{O}-\mathrm{H}$ stretching vibrations of adsorbed water on the surface of $\mathrm{SrWO}_{4}$ microcrystals.

\section{FE-SEM image analyses}

Figure 7 illustrates the FE-SEM images at low and high magnifications of $\mathrm{SrWO}_{4}$ microcrystals co-precipitated at room temperature with (a-c) $\left[\mathrm{SrNO}_{3}\right],(\mathrm{d}-\mathrm{f}) \mathrm{Sr}\left(\mathrm{CH}_{3} \mathrm{CO}_{2}\right)_{2}$, and $(\mathrm{g}-\mathrm{i})\left[\mathrm{SrCl}_{2} \cdot 6 \mathrm{H}_{2} \mathrm{O}\right]$, respectively.

Figure 7a reveals the $\mathrm{SrWO}_{4}$ microcrystals obtained with $\mathrm{SrNO}_{3}$ precursor are basically formed of several nanocrystals governed by self-assembled process, resulting in pitch pine cone-like microcrystals [61]. FE-SEM images at high magnification (Fig. $7 \mathrm{~b}$ ) proved the $\mathrm{SrWO}_{4}$ microcrystals are not dense and faceted structures. This behavior was related to significant amount of $\mathrm{SrWO}_{4}$ nanocrystals that have not completely migrated from crystal surface to internal region of pitch pine cone-like microcrystals. These microcrystals have an average size of approximately $1.8 \mu \mathrm{m}$. In Fig. 7c was noted a mutual aggregation between pitch pine cone-like microcrystals in a chemical environment under basic $\mathrm{pH}$ conditions, leading to the growth of its lateral edges (longleaf pine cone-like microcrystals). The literature [62] have reported the growth of shuttle-like $\mathrm{BaWO}_{4}$ structures in water and ethanol by means oriented attachment, which is related to assembled from several small primary nanoparticles. These same morphological shapes were identified for $\mathrm{SrWO}_{4}$ microcrystals synthesized with $\mathrm{Sr}\left(\mathrm{CH}_{3} \mathrm{CO}_{2}\right)_{2}$ precursor (Fig. $7 \mathrm{~d}-\mathrm{f}$ ); however, these microcrystals have an average size of approximately $2.2 \mu \mathrm{m}$. In Fig. $7 \mathrm{~g}$, we can verify the $\left[\mathrm{SrCl}_{2} \cdot 6 \mathrm{H}_{2} \mathrm{O}\right]$ precursor promoted an incomplete growth and agglomeration of some pitch and longleaf pine cone-like $\mathrm{SrWO}_{4}$ microcrystals. This behavior can be associated to the influence of chloride ions $\left(\mathrm{Cl}^{-}\right)$in aqueous solution, during the interaction process between $\mathrm{Sr}^{2+}$ and $\mathrm{WO}_{4}^{2-}$ ions and formation of first nanocrystals. This particular characteristic of $\mathrm{Cl}^{-}$ ions can inhibit the crystal growth process via selfassembly, resulting in defects and irregularities in the pitch and longleaf pine cone-like $\mathrm{SrWO}_{4}$ microcrystals (Fig. 7h, 
Table 2 Comparative results between our experimental Raman-active modes of $\mathrm{SrWO}_{4}$ synthesized with different strontium precursors $\left(\left[\mathrm{Sr}\left(\mathrm{NO}_{3}\right)\right]_{2} \wedge,\left[\mathrm{SrCl}_{2} \cdot 6 \mathrm{H}_{2} \mathrm{O}\right] \mathbf{\bullet}\right.$ and $\left[\mathrm{Sr}\left(\mathrm{CH}_{3} \mathrm{CO}_{2}\right)_{2}\right]$ *) with those published in the literature

\begin{tabular}{lllllll}
\hline Lattice mode symmetry $\left(C_{4 h}^{6}\right)$ & $\boldsymbol{\Lambda}$ & $\boldsymbol{\bullet}$ & $\boldsymbol{*}$ & {$[58]$} & {$[59]$} & Assignments \\
\hline$B_{g}$ & 83 & 83 & 83 & - & 75 & $v_{\mathrm{ext}}$ \\
$E_{g}$ & 100 & 100 & 100 & - & 102 & \\
$E_{g}$ & 129 & 129 & 129 & - & 133 & \\
$B_{g}$ & - & - & - & - & - & \\
$A_{g}$ & 188 & 188 & 188 & 187 & 190 & $v_{\text {r.f. }}\left(\mathrm{F}_{1}\right)$ \\
$E_{g}$ & 236 & 236 & 236 & - & 238 & \\
$A_{g}$ & 335 & 335 & 335 & 334 & 336 & $v_{2}(\mathrm{E})$ \\
$B_{g}$ & 335 & 335 & 335 & - & 336 & \\
$B_{g}$ & 370 & 370 & 370 & 373 & 374 & $v_{4}\left(\mathrm{~F}_{2}\right)$ \\
$E_{g}$ & 380 & 380 & 380 & - & - & \\
$E_{g}$ & 796 & 796 & 796 & 791 & 800 & $v_{3}\left(\mathrm{~F}_{2}\right)$ \\
$B_{g}$ & 835 & 835 & 835 & 831 & 837 & \\
$A_{g}$ & 919 & 919 & 919 & 912 & 921 & $v_{1}\left(\mathrm{~A}_{1}\right)$ \\
\hline
\end{tabular}

i). Particularly, these microcrystals have an average size of approximately $1.6 \mu \mathrm{m}$.

\section{Growth mechanism of $\mathrm{SrWO}_{4}$ crystals}

Figure 8a-e illustrates a hypothetical growth mechanism of $\mathrm{SrWO}_{4}$ microcrystals formed by the co-precipitation route at room temperature with different strontium precursors.

Figure 8a shows the initial synthesis stage of $\mathrm{SrWO}_{4}$ microcrystals by the co-precipitation reaction, which involves the solubilization in water of $\mathrm{H}_{2} \mathrm{WO}_{4}$ and different strontium precursors, $\mathrm{SrNO}_{3}, \mathrm{Sr}\left(\mathrm{CH}_{3} \mathrm{CO}_{2}\right)_{2}$, and $\mathrm{SrCl}_{2}$ $\cdot 6 \mathrm{H}_{2} \mathrm{O}$. The resulting solutions were placed in ultrasonic bath for $30 \mathrm{~min}$ to accelerate the co-precipitation rate. In the sequence, $6 \mathrm{~mL}$ of $\mathrm{NH}_{4} \mathrm{OH}$ was added in each system to intensify the ionization rate of $\mathrm{H}_{2} \mathrm{WO}_{4}$ in the aqueous solution. In this case, $\mathrm{Sr}^{2+}$ cations are electron pair acceptors (Lewis acid), which are arising from strontium precursors with distinct solubility product constant $\left[K_{s p}\right]$ in water at room temperature, such as $\left[\mathrm{SrNO}_{3}\right] \rightarrow$ $K_{s p}=70.9 \mathrm{~g} / 100 \mathrm{~mL} ;\left[\mathrm{SrCl}_{2} \cdot 6 \mathrm{H}_{2} \mathrm{O}\right] \rightarrow K_{s p}=53.8 \mathrm{~g} / 100$ $\mathrm{mL}$, and $\operatorname{Sr}\left(\mathrm{CH}_{3} \mathrm{CO}_{2}\right)_{2} \rightarrow K_{s p}=36.9 \mathrm{~g} / 100 \mathrm{~mL}$. The $\mathrm{WO}_{4}^{2-}$ anions are electron pair donors (Lewis base), which are arising from $\mathrm{H}_{2} \mathrm{WO}_{4}$ in water. The reaction at $\mathrm{pH} 10$ involving these two species $\left(\mathrm{Sr}^{2+} \leftarrow \mathrm{WO}_{4}^{2-}\right.$ ions) results in a covalent bond. The covalent bond occurs due to Lewis acid to occupy the lowest molecular orbital (LUMO), which interacts with the highest molecular orbital (HOMO) of the Lewis base. In Fig. 8b is illustrated the interaction process between $\mathrm{Sr}^{2+}$ and $\mathrm{WO}_{4}^{2-}$ ions. Before these interactions occur, the solvation energy of water molecules promotes a rapid dissociation of the salts involved in the reaction, so that the $\mathrm{Sr}^{2+}$ and $\mathrm{WO}_{4}^{2-}$ ions are rapidly solvated by the water molecules. The partial negative charge of water molecules is electrostatically attracted by $\mathrm{Sr}^{2+}$ ions, while the other positive charge is attracted by $\mathrm{WO}_{4}^{2-}$ ions [63]. However, there is a strong electrostatic attraction between $\mathrm{Sr}^{2+}$ and $\mathrm{WO}_{4}^{2-}$ ions, resulting in the formation of first $\mathrm{SrWO}_{4}$ precipitates or nucleation seeds. After this interaction, instantaneously occurs the formation of first nucleation seeds (Fig. 8c). These nuclei interact with other, forming the $\mathrm{SrWO}_{4}$ nanocrystals (pine nut-like nanocrystals), which are able to grow via self-assembly mechanism (Fig. 8d). Basically, in this type of growth mechanism, there is a spontaneous and mutual aggregation between nanocrystals by means of uncountable collision events (particle-particle interactions) followed by the coalescence of $\mathrm{SrWO}_{4}$ nanocrystals. The growth and agglomeration of these nanocrystals promotes the origin of complex superstructures or large $\mathrm{SrWO}_{4}$ microcrystals. It is important to highlight that the average yield (\%) results for the formation of nanoparticles of each strontium precursor are correlated with their solubility product constants at $28{ }^{\circ} \mathrm{C} /$ $100 \mathrm{~mL}$ in water. On the other hand, when $\mathrm{SrNO}_{3}$, $\mathrm{Sr}\left(\mathrm{CH}_{3} \mathrm{CO}_{2}\right)_{2}$, and $\mathrm{SrCl}_{2} \cdot 6 \mathrm{H}_{2} \mathrm{O}$ precursors were used in the co-precipitation synthesis, there is the formation of pitch and longleaf pine cone-like $\mathrm{SrWO}_{4}$ microcrystals (Fig. 8d). In principle, we report, based on our FE-SEM images, that longleaf pine cone-like $\mathrm{SrWO}_{4}$ microcrystals are originated by the aggregation of several pitch pine cone-like microcrystals (Fig. 8e). The formation and growth of these microcrystals are in agreement with the morphological aspects of other tungstates published in the literature [63].

\section{UV-Vis diffuse reflectance spectroscopy analyses}

The optical band gap energy $\left(E_{\text {gap }}\right)$ values were calculated by the Kubelka-Munk equation [64], which is based on the transformation of diffuse reflectance measurements to estimate $E_{\text {gap }}$ values with good accuracy [65]. Particularly, it is used in limited cases of infinitely thick samples. The Kubelka-Munk equation for any wavelength is described by 

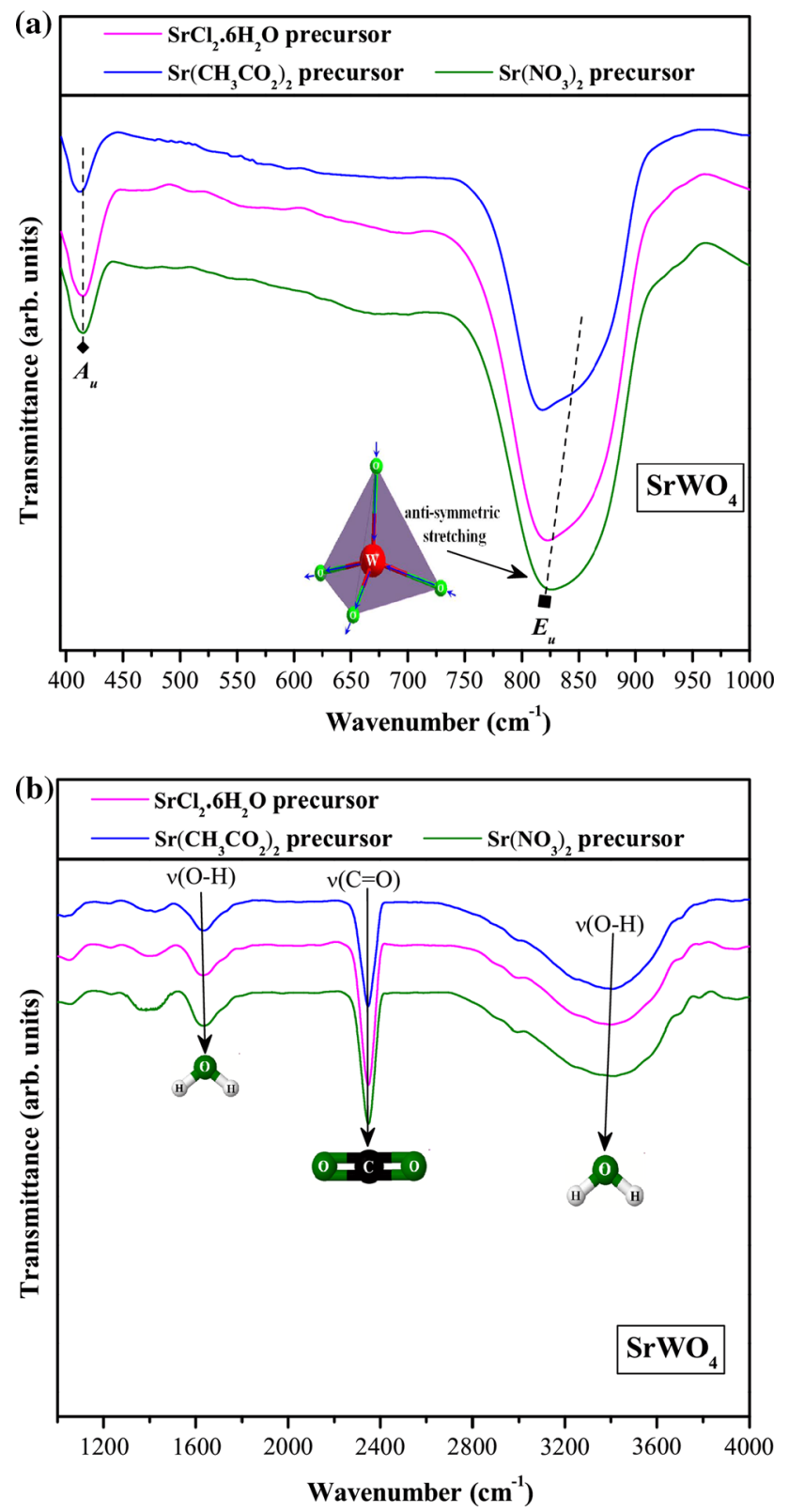

Fig. 6 FT-IR spectra in the range from: a 395 to $1000 \mathrm{~cm}^{-1}$ and b 1000 to $4000 \mathrm{~cm}^{-1}$ of $\mathrm{SrWO}_{4}$ microcrystals synthesized with different strontium precursors. The vertical lines dashed indicate the positions of IR-active modes

$\frac{K}{S}=\frac{\left(1-R_{\infty}\right)^{2}}{2 R_{\infty}} \equiv F\left(R_{\infty}\right)$,

where $F\left(R_{\infty}\right)$ is the Kubelka-Munk function or absolute reflectance of the sample. In our case, magnesium oxide $(\mathrm{MgO})$ was adopted as standard sample in reflectance measurements; $R_{\infty}=R_{\mathrm{sample}} / R_{\mathrm{MgO}}\left(R_{\infty}\right.$ is the reflectance), $K$ is the molar absorption coefficient, and $S$ is the scattering coefficient. In a parabolic band structure, the optical band gap and absorption coefficient of semiconductor oxides [66] can be calculated by the following equation:

$\alpha h v=C_{1}\left(h v-E_{\text {gap }}\right)^{n}$,

where $\alpha$ is the linear absorption coefficient of the material, $h v$ is the photon energy, $C_{1}$ is a proportionality constant, $E_{\text {gap }}$ is the optical band gap, and $n$ is a constant associated with different types of electronic transitions $(n=1 / 2$ for direct allowed, $n=2$ for indirect allowed, $n=1.5$ for direct forbidden, and $n=3$ for indirect forbidden). According to the theoretical calculations reported in the literature [67], scheelite $\left(\mathrm{ABO}_{4}\right)$ crystals exhibit an optical absorption spectrum governed by direct electronic transitions. In this phenomenon, after the electronic absorption, the electrons located in minimum energy states in the conduction band (CB) are able to go back to maximum energy states of the valence band (VB) in the same points in the Brillouin zone [68]. Based on this information, $E_{\text {gap }}$ values of our $\mathrm{SrWO}_{4}$ microcrystals were calculated using $n=1 / 2$ in Eq. 11. Finally, using the diffuse reflectance function described in Eq. 10 with $K=2 \alpha$, we obtain the modified Kubelka-Munk equation as indicated in Eq. (12):

$\left[F\left(\mathrm{R}_{\infty}\right) h v\right)^{2}=C_{2}\left(h v-E_{\text {gap }}\right)$.

Therefore, finding the $F\left(R_{\infty}\right)$ value from Eq. (12) and plotting a graph of $\left[F\left(R_{\infty}\right) h v\right]^{2}$ versus $h v, E_{\text {gap }}$ values of all $\mathrm{SrWO}_{4}$ microcrystals can be calculated extrapolating the linear portion of UV-Vis curves.

Figure 9a-c shows UV-Vis spectra of $\mathrm{SrWO}_{4}$ microcrystals co-precipitated at room temperature with different strontium precursors.

In this figure, there is slight changes in $E_{\text {gap }}$ values according to the type of strontium precursor employed in the synthesis of $\mathrm{SrWO}_{4}$ microcrystals. The exponential optical absorption edge and $E_{\text {gap }}$ are controlled by the degree of structural order-disorder in the lattice [69]. Therefore, the lowest $E_{\text {gap }}(4.84 \mathrm{eV})$ was detected for $\mathrm{SrWO}_{4}$ microcrystals obtained with $\mathrm{SrNO}_{3}$ precursor, suggesting the existence of uncountable intermediary energy levels within the forbidden band gap, as a consequence of a high defect density in the lattice, such as distortions in $\mathrm{O}-\mathrm{W}-\mathrm{O}$ or $\mathrm{O}-\mathrm{Sr}-\mathrm{O}$ bonds, oxygen vacancies, cracks, pores, dislocations, grain boundaries, etc. $\mathrm{SrWO}_{4}$ microcrystals prepared with $\mathrm{SrCl}_{2} \cdot 6 \mathrm{H}_{2} \mathrm{O}$ and $\operatorname{Sr}\left(\mathrm{CH}_{3} \mathrm{CO}_{2}\right)_{2}$ precursors exhibited $E_{\text {gap }}$ of 4.87 and $5.0 \mathrm{eV}$, respectively (Fig. 9b, c). These results suggest a lower concentration of structural defects in these microcrystals in relation to those obtained with $\mathrm{SrNO}_{3}$ precursor. It is important to highlight that the types as well as the contribution single or joint of these energy levels within the band gap in these microcrystals can be achieved only by means of theoretical calculations. 

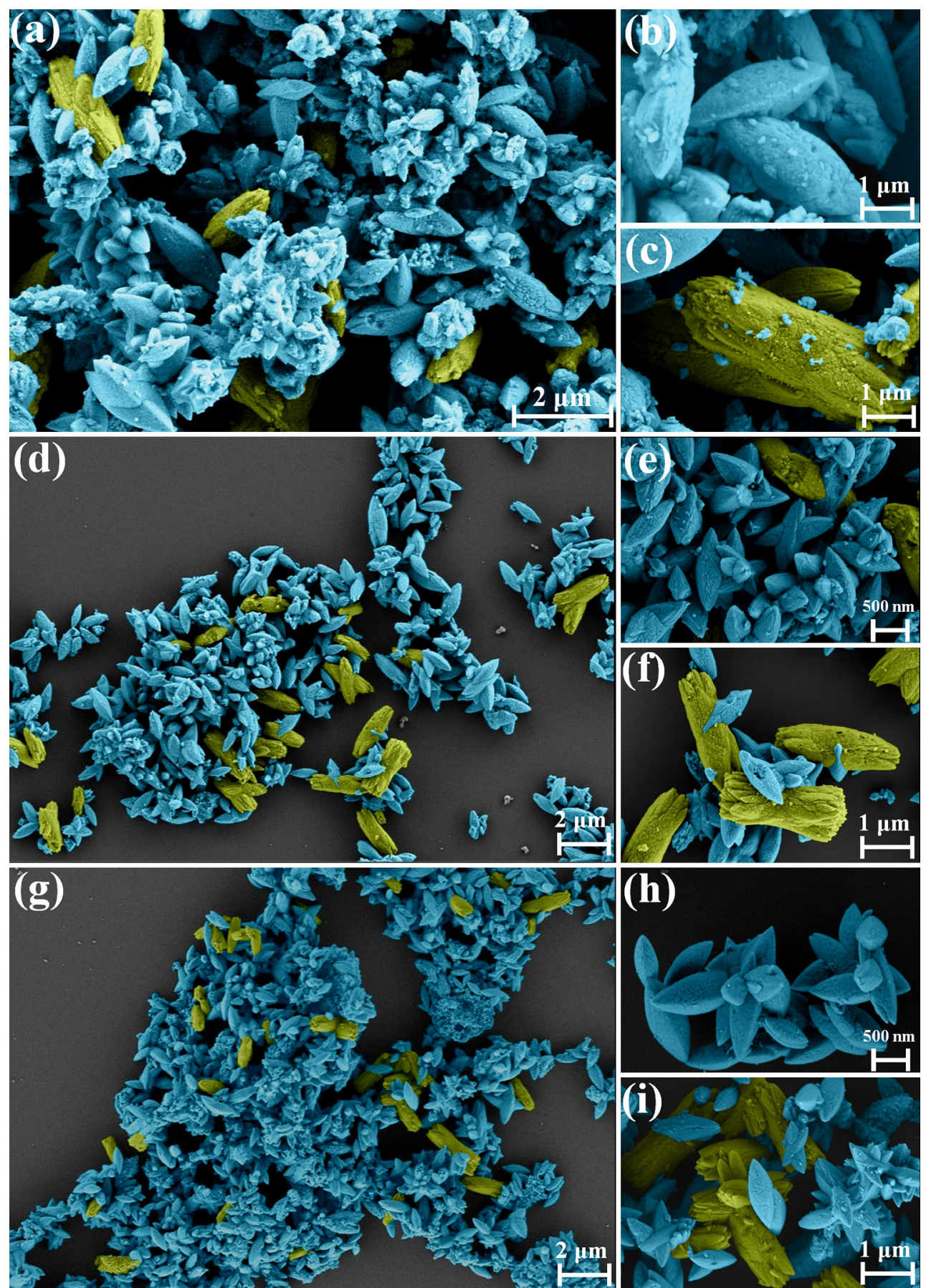

Fig. 7 FE-SEM images at low and high resolution of $\mathrm{SrWO}_{4}$ microcrystals synthesized with a-c $\mathrm{SrNO}_{3}, \mathbf{d}-\mathbf{f} \mathrm{Sr}\left(\mathrm{CH}_{3} \mathrm{CO}_{2}\right)_{2}$, and $\mathbf{g}-\mathbf{i} \mathrm{SrCl}{ }_{2} \cdot 6 \mathrm{H}_{2} \mathrm{O}$

\section{PL emission analyses}

Figure 10 illustrates PL spectra recorded at room temperature of $\mathrm{SrWO}_{4}$ microcrystals co-precipitated at room temperature with different strontium precursors.

These PL spectra present a broad band covering a large part of visible electromagnetic spectra (from 380 to $600 \mathrm{~nm}$ ), indicating a contribution of several energy states within the band gap. These states are related to the numerous types of defects directly associated to the degree of structural order-disorder in the lattice. Topological disorder is a type of disorder associated with glassy and amorphous solid structures, in which the structure cannot be defined in terms of a periodic lattice. According to the literature [70-72], the blue-green PL emissions of $\mathrm{SrWO}_{4}$ are caused by the surface and structural defects, particle 
Fig. 8 Proposed growth mechanism of $\mathrm{SrWO}_{4}$ microcrystals synthesized with different strontium precursors $\left[\mathrm{SrNO}_{3}, \mathrm{SrCl}_{2} \cdot 6 \mathrm{H}_{2} \mathrm{O}\right.$, and $\left.\mathrm{Sr}\left(\mathrm{CH}_{3} \mathrm{CO}_{2}\right)_{2}\right]$ in a aqueous solution; b electrostatic attraction between $\mathrm{Sr}^{2+}$ and $\mathrm{WO}_{4}^{2-}$ ions in solution; c formation and interaction of first nucleation seeds, resulting in $\mathrm{SrWO}_{4}$ nanocrystals; d growth stage of nanocrystals (pine nut-like nanocrystals) via self-assembly mechanism, forming pitch cone-like microcrystals; and e mutual aggregation of several pitch pine cone-like microcrystals, resulting in longleaf pine conelike microcrystals

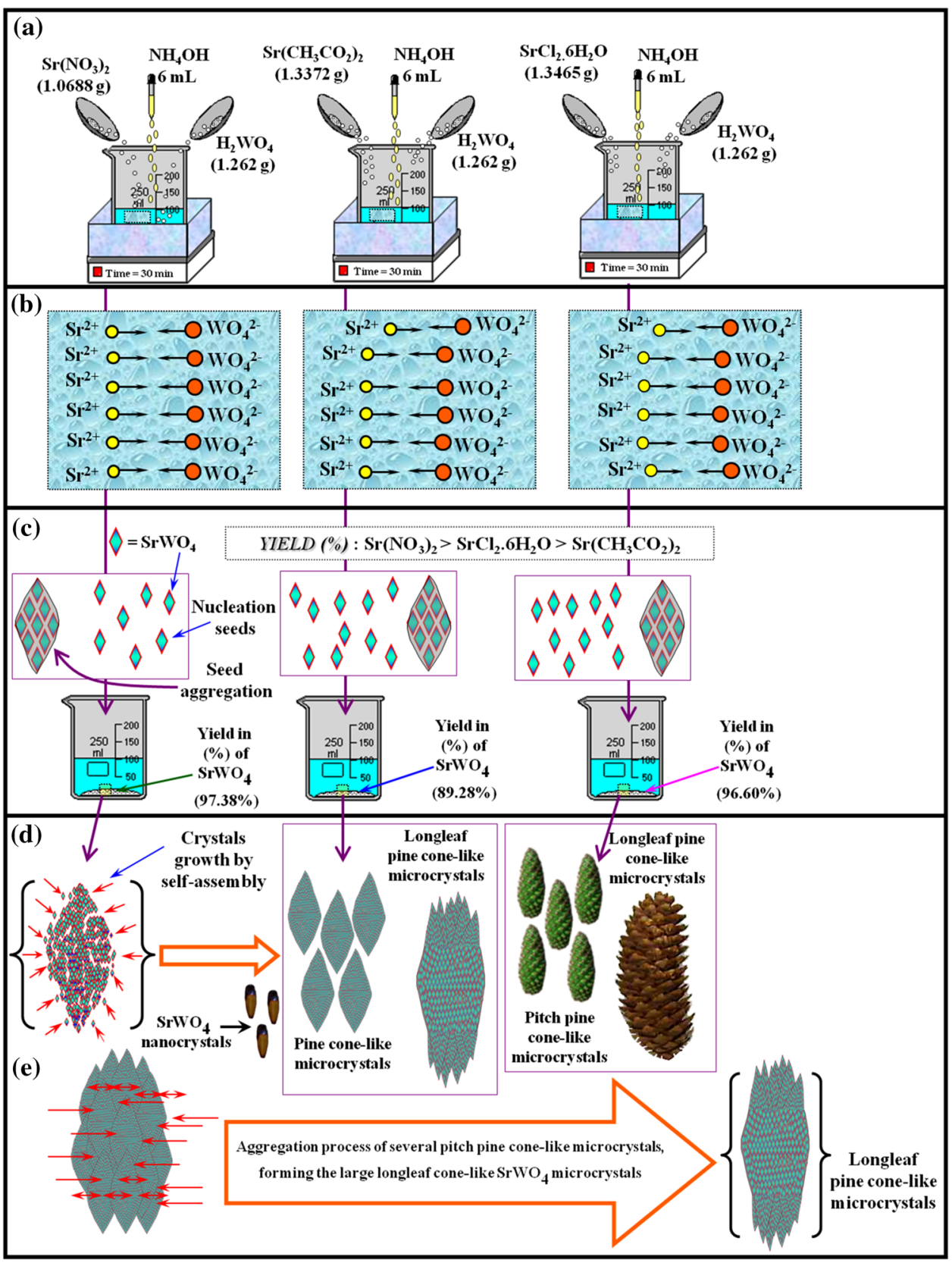

shapes, narrow particle size distribution, Jahn-Teller splitting effect in $\left[\mathrm{WO}_{4}^{2-}\right]$ tetrahedron, preferred orientation, etc. Based on our Rietveld refinements and UV-Vis spectra, there is the possibility of electronic transitions involving single clusters $\left(\left[\mathrm{WO}_{4}\right]\right.$ or $\left.\left[\mathrm{SrO}_{8}\right]\right)$ or from cluster to cluster $\left(\left[\mathrm{WO}_{4}\right]-\left[\mathrm{SrO}_{8}\right]\right.$ and/or $\left.\left[\mathrm{SrO}_{8}\right]-\left[\mathrm{SrO}_{8}\right]\right)$ in the PL response of $\mathrm{SrWO}_{4}$ microcrystals. Basically, PL properties of solids can be influenced by the concentration of different intrinsic (bulk/surface) and extrinsic defects (structural order-disorder), which are responsible for the modifications in the number of intermediary energy states within the band gap. These structural defects are able to promote a symmetry break, causing a polarization in the $\mathrm{SrWO}_{4}$ structure by the electronic charge transfer from ordered $(o)$ to disordered $(d)$ clusters (formation of $e-h^{\bullet}$ pairs). Hence, we presume the existence of four types of complex clusters, in which the first and second are more distorted $(d)$ and assigned as $\left[\mathrm{WO}_{4}\right]_{d}$ and $\left[\mathrm{SrO}_{4}\right]_{d}$ clusters, respectively. The third and fourth are considered less distorted or ordered $(o)$ and designed as $\left[\mathrm{WO}_{4}\right]_{o}$ and $\left[\mathrm{SrO}_{4}\right]_{o}$ clusters. In this proposed mechanism, the possible charge transfers between $\left[\mathrm{WO}_{4}\right]_{d^{-}}^{x}-\left[\mathrm{SrO}_{8}\right]_{o}^{x}, \quad\left[\mathrm{SrO}_{8}\right]_{d^{-}}^{x}\left[\mathrm{WO}_{4}\right]_{o}^{x}, \quad\left[\mathrm{WO}_{4}\right]_{d^{-}}^{x}\left[\mathrm{SrO}_{8}\right]_{o}^{x}-$ $\left[\mathrm{WO}_{4}\right]_{o}^{x}$, and $\left[\mathrm{SrO}_{8}\right]_{d}^{x}-\left[\mathrm{WO}_{4}\right]_{o}^{x}-\left[\mathrm{SrO}_{8}\right]_{o}^{x}$ clusters are shown in the following equations below: 

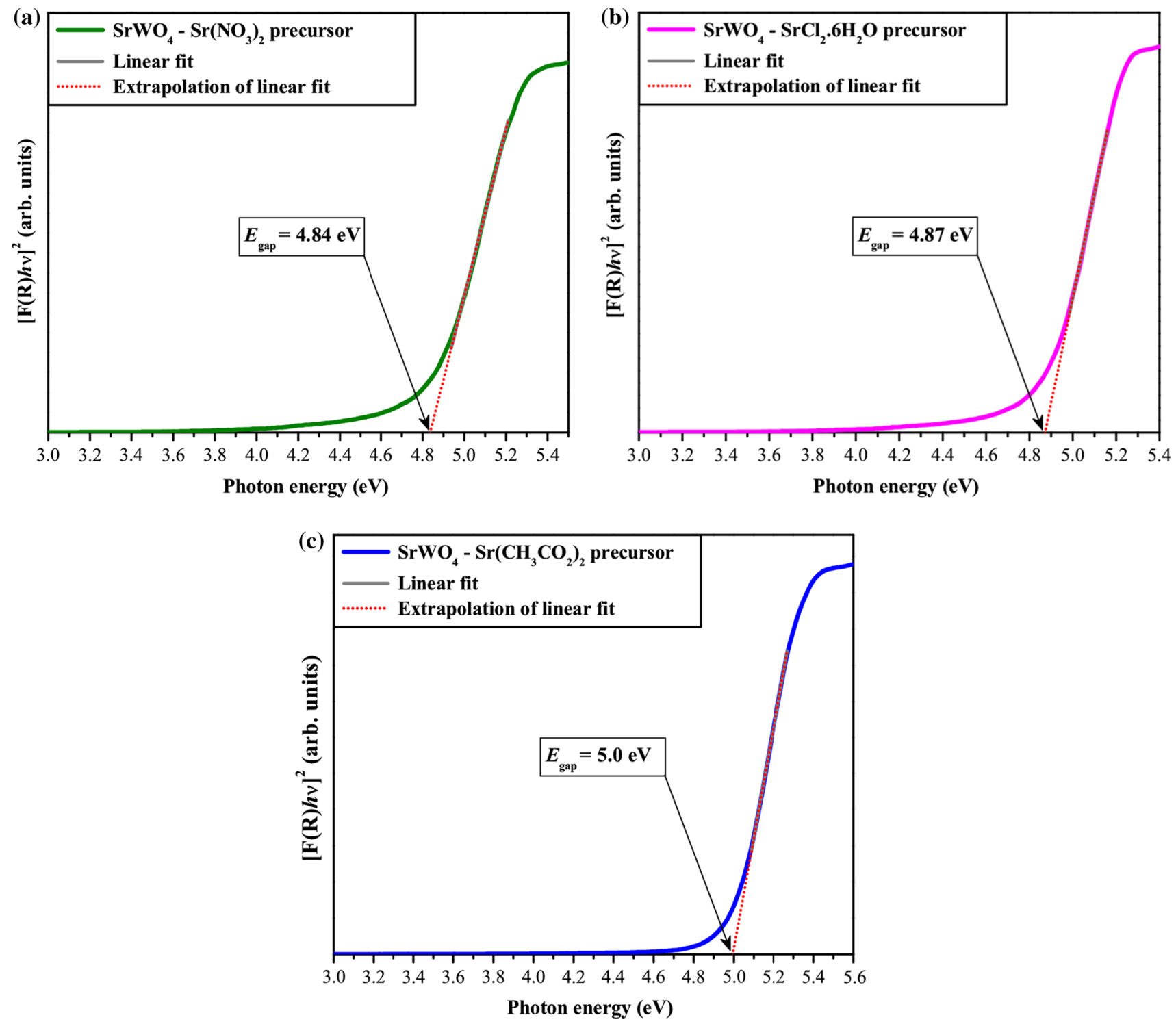

Fig. 9 UV-Vis spectra of $\mathrm{SrWO}_{4}$ microcrystals synthesized with different strontium precursors

$$
\begin{aligned}
& h v(\text { Excitation }=\lambda=350 \mathrm{~nm})\left[\mathrm{WO}_{4}\right]_{d}^{x} \stackrel{e^{\prime}}{\longrightarrow}\left[\mathrm{SrO}_{8}\right]_{o}^{x} \rightarrow\left[\mathrm{WO}_{4}\right]_{d}^{\cdot}-\left[\mathrm{SrO}_{8}\right]_{o}^{\prime} \\
& {\left[\mathrm{SrO}_{8}\right]_{d}^{x} \stackrel{e^{\prime}}{\longrightarrow}\left[\mathrm{WO}_{4}\right]_{o}^{x} \rightarrow\left[\mathrm{SrO}_{8}\right]_{d}^{\cdot}-\left[\mathrm{WO}_{4}\right]_{o}^{\prime}} \\
& {\left[\mathrm{WO}_{4}\right]_{d}^{x} \stackrel{e^{\prime}}{\rightarrow}\left[\mathrm{SrO}_{8}\right]_{o}^{x}-\left[\mathrm{WO}_{4}\right]_{o}^{x} \rightarrow\left[\mathrm{WO}_{4}\right]_{d}^{{ }^{\prime}}-\left[\mathrm{SrO}_{8}\right]_{o}^{\prime}} \\
& -\left[\mathrm{WO}_{4}\right]_{o}^{x} \rightarrow\left[\mathrm{WO}_{4}\right]_{d}^{\cdot}-\left[\mathrm{SrO}_{8}\right]_{o}^{x}-\left[\mathrm{WO}_{4}\right]_{o}^{\prime} \\
& {\left[\mathrm{SrO}_{8}\right]_{d}^{x} \stackrel{e^{\prime}}{\rightarrow}\left[\mathrm{WO}_{4}\right]_{o}^{x}-\left[\mathrm{SrO}_{8}\right]_{o}^{x} \rightarrow\left[\mathrm{SrO}_{8}\right]_{d}^{\cdot}-\left[\mathrm{WO}_{4}\right]_{o}^{\prime}} \\
& -\left[\mathrm{SrO}_{8}\right]_{o}^{x} \rightarrow\left[\mathrm{SrO}_{8}\right]_{d}^{\cdot}-\left[\mathrm{WO}_{4}\right]_{o}^{x}-\left[\mathrm{SrO}_{8}\right]_{o}^{\prime} \stackrel{h v^{\prime}(\text { Emission } \neq \lambda \neq 350 \mathrm{~nm})}{\longrightarrow} \text {. }
\end{aligned}
$$

In Eqs. (13-16), the cluster-to-cluster charge transfer (CCCT) in a crystal containing more than one type of cluster is characterized by excitations involving electronic transitions from one cluster to another cluster. During the excitation process at room temperature, the electrons situated at lower intermediary energy levels (O $2 p$ orbitals) absorb the photon energies $(h v)(350 \mathrm{~nm} \approx 3.54 \mathrm{eV})$. As consequence of this phenomenon, the energetic electrons are promoted to higher intermediary energy levels (W $5 d$ orbitals) located near the CB. When the electrons fall back to lower energy states, the energies arising from these electronic transitions are converted in photons $\left(h v^{\prime}\right)$. In this case, the several photons $\left(h v^{\prime}\right)$ originated by the participation of different energy states during the electronic transitions are responsible for the broad PL spectra. In addition, PL profiles of $\mathrm{SrWO}_{4}$ microcrystals exhibit different emissions intensities, depending on the type of 


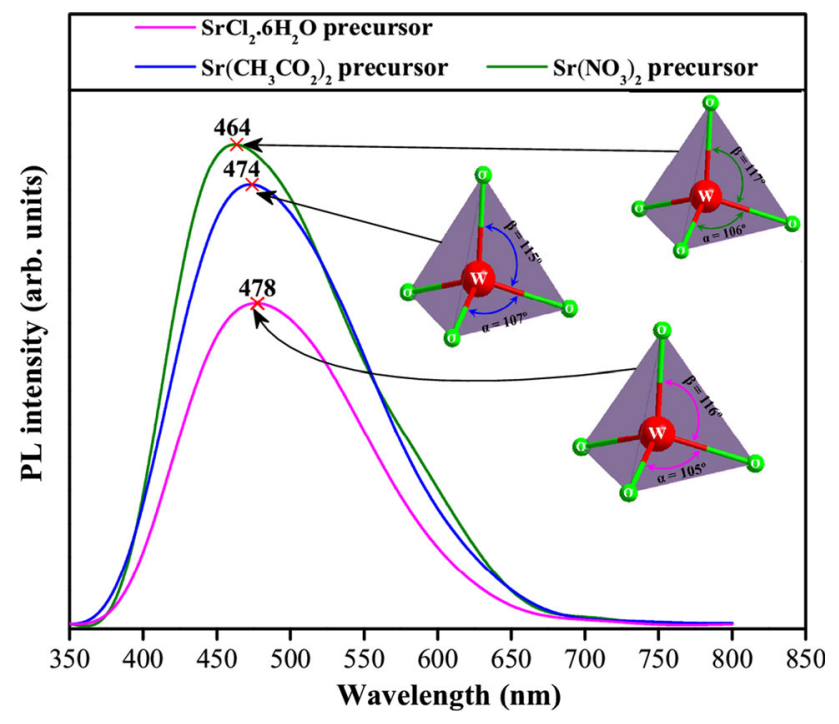

Fig. 10 PL spectra of $\mathrm{SrWO}_{4}$ microcrystals synthesized with different precursors salts

strontium precursor (Fig. 10). Moreover, insets in Fig. 10 illustrate different $\mathrm{O}-\mathrm{W}-\mathrm{O}$ bond angles $(\alpha$ and $\beta$ ), suggesting that the tetrahedral $\left[\mathrm{WO}_{4}\right]$ clusters are distorted in the lattice. These bond angles were estimated using the lattice parameters and atomic positions obtained from Rietveld refinements as input data in the crystal and molecular structure visualization software [42]. These distortions are key factors for the origin of intermediary energy states within the forbidden region, influencing in the PL response of $\mathrm{SrWO}_{4}$ microcrystals.

\section{Conclusion}

In summary, $\mathrm{SrWO}_{4}$ microcrystals were synthesize by the co-precipitation method at room temperature with different strontium precursors $\left[\mathrm{SrNO}_{3}, \mathrm{SrCl}_{2} \cdot 6 \mathrm{H}_{2} \mathrm{O}\right.$, and $\mathrm{Sr}\left(\mathrm{CH}_{3-}\right.$ $\left.\mathrm{CO}_{2}\right)_{2}$ ]. XRD patterns and Rietveld refinements revealed the $\mathrm{SrWO}_{4}$ microcrystals have a scheelite-type tetragonal structure with a good degree of crystallinity (ordered at long range), in which the $\left[\mathrm{WO}_{4}\right]$ clusters are slightly distorted in the lattice. Independent of the type of strontium precursor, FT-Raman spectra showed the $\mathrm{SrWO}_{4}$ microcrystals have well-defined vibrational bands, suggesting a structurally ordered matrix at short range. FT-IR spectra detected the IR-active modes of typical anti-symmetric stretching vibrations of tetrahedral $\left[\mathrm{WO}_{4}\right]$ clusters. According to the XANES spectra, all samples obtained in this work have their $\mathrm{W}$ atoms bonded to four oxygens ([WO 4$]$ clusters). The calculated area of the $\mathrm{W} \mathrm{L}_{1}$-edge peaks indicated the $\mathrm{SrWO}_{4}$ microcrystals synthesized with $\mathrm{SrNO}_{3}$ have a strong interaction between $\mathrm{O}-\mathrm{W}-\mathrm{O}$ bonds in relation to other precursors. In morphological terms,
$\mathrm{SrWO}_{4}$ is composed of pitch and longleaf pine cone-like microcrystals, when the $\mathrm{SrNO}_{3}, \mathrm{SrCl}_{2} \cdot 6 \mathrm{H}_{2} \mathrm{O}$, and $\mathrm{Sr}\left(\mathrm{CH}_{3}\right.$ $\left.\mathrm{CO}_{2}\right)_{2}$ precursors were used in the co-precipitation synthesis. Comparing the $E_{\text {gap }}$ values, the results demonstrated the type of strontium precursor used in the formation of $\mathrm{SrWO}_{4}$ microcrystals is able to originate distinct quantities and/or distributions of intermediary energy states within the band gap. The lowest $E_{\text {gap }}$ was detected for $\mathrm{SrWO}_{4}$ microcrystals obtained with $\mathrm{SrNO}_{3}$ precursor, suggesting a structure with a high concentration of structural defects. The differences in PL profiles, especially in terms of intensity, were related to electronic transitions in distorted $\left[\mathrm{WO}_{4}\right]$ clusters and/or from cluster to cluster $\left(\left[\mathrm{WO}_{4}\right] \rightarrow\right.$ $\left[\mathrm{SrO}_{8}\right]$ and/or $\left.\left[\mathrm{SrO}_{8}\right] \rightarrow\left[\mathrm{SrO}_{8}\right]\right)$.

Acknowledgements The authors acknowledge the financial support of the following Brazilian research funding institutions: the FAPESP (2012/14004-5; 2013/07296-2), CNPq (304531/2013-8; 479644/ 2012-8), National Laboratory of Synchrotron Light (D04B-XAFS111883), and CAPES.

\section{References}

1. Fan L, Fan YX, Duan YH, Wang Q, Wang HT, Jia GH, Tu CY (2009) Continuous-wave intracavity Raman laser at $1179.5 \mathrm{~nm}$ with $\mathrm{SrWO}_{4}$ Raman crystal in diode-end-pumped $\mathrm{Nd}: \mathrm{YVO}_{4}$ laser. Appl Phys B 94:553-557

2. Wang A, Wang C, Jia G (2009) Recent advances in strontium tungstate scheelite material. Front Chem China 5:61-70

3. Liao J, Qiu B, Wen H, Chen J, You W, Liu L (2009) Synthesis process and luminescence properties of $\mathrm{Tm}^{3+}$ in $\mathrm{AWO}_{4}(\mathrm{~A}=\mathrm{Ca}$, Sr, Ba) blue phosphors. J Alloys Compd 487:758-762

4. Shan Z, Wang Y, Ding H, Huang F (2009) Structure-dependent photocatalytic activities of $\mathrm{MWO}_{4}(\mathrm{M}=\mathrm{Ca}, \mathrm{Sr}, \mathrm{Ba})$. J Mol Catal A 302:54-58

5. Cavalcante LS, Sczancoski JC, Batista NC, Longo E, Varela JA, Orlandi MO (2013) Growth mechanism and photocatalytic properties of $\mathrm{SrWO}_{4}$ microcrystals synthesized by injection of ions into a hot aqueous solution. Adv Powder Technol 24:344-353

6. Lou Z, Cocivera M (2002) Cathodoluminescence of $\mathrm{CaWO}_{4}$ and $\mathrm{SrWO}_{4}$ thin films prepared by spray pyrolysis. Mater Res Bull 37:1573-1582

7. Fan JD, Zhang HJ, Wang JY, Jiang MH, Boughton RI, Ran DG, Sun SQ, Xia HR (2006) Growth and thermal properties of $\mathrm{SrWO}_{4}$ single crystal. J Appl Phys 100:063513-063518

8. Fan YX, Liu Y, Duan Y, Wang Q, Fan L, Wang HT, Jia GH, Tu CY (2008) High-efficiency eye-safe intracavity Raman laser at $1531 \mathrm{~nm}$ with $\mathrm{SrWO}_{4}$ crystal. Appl Phys B 93:327-330

9. Porto SL, Longo E, Pizani PS, Boschi TM, Simões LGP, Lima SJG, Ferreira JM, Soledade LEB, Espinosa JWM, Cássia-Santos MR, Maurera MAMA, Paskocimas CA, Santos IMG, Souza AG (2008) Photoluminescence in the $\mathrm{Ca}_{x} \mathrm{Sr}_{1-x} \mathrm{WO}_{4}$ system at room temperature. J Solid State Chem 181:1876-1881

10. Tian G, Sun S (2011) Additive induced morphology changes of nano-crystalline $\mathrm{SrWO}_{4}$. Cryst Res Technol 46:389-392

11. Dong FJ, Hu ZA, Zheng WP, Wen GW, Ji WY (2006) Synthesis of polycrystalline materials of $\mathrm{SrWO}_{4}$ and growth of its single crystal. Front Chem China 1:264-267

12. Yang S, Sun J (2004) Synthesis and properties of $\mathrm{Tb}^{3+}$-doped $\mathrm{Ca}_{x} \mathrm{Sr}_{1-x} \mathrm{WO}_{4}$. J Rare Earths 22:331-333 
13. Caprez A, Meyer P, Mikhail P, Hulliger J (1997) New hostlattices for hyperfine optical hole burning: materials of low nuclear spin moment. Mater Res Bull 32:1045-1054

14. Errandonea D, Pellicer-Porres J, Manjón FJ, Segura A, FerrerRoca C, Kumar RS, Tschauner O, Rodriguez-Hernandez P, Lopez-Solano J, Radescu S, Mujica A, Munoz A, Aquilanti G (2005) High-pressure structural study of the scheelite tungstates $\mathrm{CaWO}_{4}$ and $\mathrm{SrWO}_{4}$. Phys Rev B 72:174106-174119

15. Patel AR, Arora SK (1974) Crystal growth of $\mathrm{BaWO}_{4}$ and $\mathrm{SrWO}_{4}$ by flux evaporation. J Cryst Growth 23:95-100

16. Chen L, Gao Y (2009) Electro-deposition of luminescent molybdate and tungstate thin films via a cell route. Mater Chem Phys 116:242-246

17. Jiang X, Ma J, Yao Y, Sun Y, Liu Z, Ren Y, Liu J, Lin B (2009) Low-temperature synthesis of $\mathrm{SrWO}_{4}$ nano-particles by a molten salt method. Ceram Int 35:3525-3528

18. Thongtem T, Phuruangrat A, Thongtem S (2008) Characterization of $\mathrm{MeWO}_{4}(\mathrm{Me}=\mathrm{Ba}, \mathrm{Sr}$ and $\mathrm{Ca})$ nanocrystallines prepared by sonochemical method. Appl Surf Sci 254:7581-7585

19. Rangappa D, Fujiwara T, Watanabe T, Yoshimura M (2008) Preparation of $\mathrm{Ba}_{1-x} \mathrm{Sr}_{x} \mathrm{WO}_{4}$ and $\mathrm{Ba}_{1-x} \mathrm{Ca}_{x} \mathrm{WO}_{4}$ films on tungsten plate by mechanically assisted solution reaction at room temperature. Mater Chem Phys 109:217-223

20. Maurera MAMA, Souza AG, Soledade LEB, Pontes FM, Longo E, Leite ER, Varela JA (2004) Microstructural and optical characterization of $\mathrm{CaWO}_{4}$ and $\mathrm{SrWO}_{4}$ thin films prepared by a chemical solution method. Mater Lett 58:727-732

21. Huang JY, Jia QX (2003) Structural properties of $\mathrm{SrWO}_{4}$ films synthesized by pulsed-laser deposition. Thin Solid Films 444:95-98

22. Chen Z, Gong Q, Zhu J, Yuan YP, Qian LW, Qian XF (2009) Controllable synthesis of hierarchical nanostructures of $\mathrm{CaWO}_{4}$ and $\mathrm{SrWO}_{4}$ via a facile low temperature route. Mater Res Bull 44:45-50

23. Sun L, Guo Q, Wu X, Luo S, Pan W, Huang K, Lu J, Ren L, Cao M, Hu C (2007) Synthesis and photoluminescent properties of strontium tungstate nanostructures. J Phys Chem C 111:532-537

24. Ciminelli VST, Dias A (2000) Theoretical predictions and experimental results of the hydrothermal processing of strontium tungstates. Ferroelectrics 241:271-278

25. Thongtem T, Phuruangrat A, Thongtem S (2010) Microwaveassisted synthesis and characterization of $\mathrm{SrMoO}_{4}$ and $\mathrm{SrWO}_{4}$ nanocrystals. J Nanopart Res 12:2287-2294

26. Sczancoski JC, Cavalcante LS, Joya MR, Espinosa JWM, Pizani PS, Varela JA, Longo E (2009) Synthesis, growth process and photoluminescence properties of $\mathrm{SrWO}_{4}$ powders. J Colloid Interface Sci 330:227-236

27. Ryu EK, Huh YD (2008) Morphology-controlled synthesis of $\mathrm{SrWO}_{4}$ crystals. Mater Lett 62:3081-3083

28. Thongtem T, Phuruangrat A, Thongtem S (2008) Preparation and characterization of nanocrystalline $\mathrm{SrWO}_{4}$ using cyclic microwave radiation. Curr Appl Phys 8:189-197

29. Pereira PFS, Nogueira IC, Longo E, Nassar EJ, Rosa ILV, Cavalcante LS (2015) Rietveld refinement and optical properties of $\mathrm{SrWO}_{4}: \mathrm{Eu}^{3+}$ powders prepared by the non-hydrolytic sol-gel method. J Rare Earths 33:113-128

30. Zhang L, Bai Q, Wang L, Zhang A, Zhang Y, Xing Y (2014) Synthesis and electrochemical properties of $\mathrm{SrWO}_{4} /$ graphene composite as anode material for lithium-ion batteries. Funct Mater Lett 7:1450010-1450013

31. Sharma JC, Vijay A, Bhardwaj S (2013) Photocatalytic activity of a novel compound $\mathrm{SrWO}_{4}$ : removal of toxic metal lead (II) from water. World Appl Sci J 23:208-212

32. Gouveia AF, Sczancoski JC, Ferrer MM, Lima AS, Santos MRMC, Li MS, Santos RS, Longo E, Cavalcante LS (2014) Experimental and theoretical investigations of electronic structure and photoluminescence properties of $\beta-\mathrm{Ag}_{2} \mathrm{MoO}_{4}$ microcrystals. Inorg Chem 53:5589-5599
33. Rodriguez-Hernandez P, Lopez-Solano J, Radescu S, Mujica A, Munoz A, Errandonea D, Pellicer-Porres J, Segura A, FerrerRoca C, Manjón FJ, Kumar RS, Tschauner O, Aquilanti G (2006) Theoretical and experimental study of $\mathrm{CaWO}_{4}$ and $\mathrm{SrWO}_{4}$ under pressure. J Phys Chem Solids 67:2164-2171

34. Rietveld HM (1969) A profile refinement method for nuclear and magnetic structures. J Appl Cryst 2:65-71

35. Larson AC, Von Dreele RB (1994) General structure analysis system (GSAS), Los Alamos National Laboratory Report LAUR. 86:748-768

36. Chebyshev PL (1854) Théorie des mécanismes connus sous le nom de parallélogrammes. Mémoires des Savants trangers prsents-Acadmie de Saint-Ptersbourg. 7:539-586

37. Thompson P, Cox DE, Hastings JB (1987) Rietveld refinement of Debye-Scherrer synchrotron X-ray data from $\mathrm{Al}_{2} \mathrm{O}_{3}$. J Appl Cryst 20:79-83

38. Finger LW, Cox DE, Jephcoat AP (1994) A correction for powder diffraction peak asymmetry due to axial divergence. J Appl Cryst 27:892-900

39. Stephens PW (1999) Phenomenological model of anisotropic peak broadening in powder diffraction. J Appl Crystallogr 32:281-289

40. Hallaoui A, Taoufyq A, Arab M, Bakiz B, Benlhachemi A, Bazzi L, Villain S, Valmalettea JC, Guinnetona F, Gavarri JR (2015) Influence of chemical substitution on the photoluminescence of $\mathrm{Sr}_{(1-x)} \mathrm{Pb}_{x} \mathrm{WO}_{4}$ solid solution. J Solid State Chem 227:186-195

41. Pereira PFS, de Moura AP, Nogueira IC, Lima MVS, Longo E, de Sousa Filho PC, Serra OA, Nassar EJ, Rosa ILV (2012) Study of the annealing temperature effect on the structural and luminescent properties of SrWO4: Eu phosphors prepared by a non-hydrolytic sol-gel process. J Alloys Compd 526:11-21

42. http://www.crystalimpact.com/diamond/

43. Li Q, Jia C (2014) Synthesis and characteristics of $\mathrm{SrWO}_{4}: \mathrm{Sm}^{3+}$ nanofiber phosphors by electrospinning method. Nanosci Nanotechnol Lett 6:1014-1017

44. Chen Y, Wu QS, Ding YP (2007) Oil/water interface synthesis and optical property of strontium tungstate nanorods. Nano 2:195-199

45. Jia G, Wang C, Xu S (2010) Local site symmetry determination of scheelite-type structures by Eu ${ }^{3+}$ spectroscopy. J Phys Chem C 114:17905-17913

46. Krayzman V, Levin I, Woicik JC, Yoder D, Fischer DA (2006) Effects of local atomic order on the pre-edge structure in the Ti-K $\mathrm{X}$-ray absorption spectra of perovskite $\mathrm{CaTi}_{1-x} \mathrm{Zr}_{x} \mathrm{O}_{3}$. Phys Rev B 74:224104-224110

47. Gracia L, Longo VM, Cavalcante LS, Beltran A, Avansi W, Li MS, Mastelaro VR, Varela JA, Longo E, Andres J (2011) Presence of excited electronic state in $\mathrm{CaWO}_{4}$ crystals provoked by a tetrahedral distortion: an experimental and theoretical investigation. J Appl Phys 110:043501-043511

48. Cavalcante LS, Almeida MAP, Avansi W Jr, Tranquilin RL, Longo E, Batista NC, Mastelaro VR, Li MS (2013) Cluster coordination and photoluminescence properties of $\alpha-\mathrm{Ag}_{2} \mathrm{WO}_{4}$ microcrystals. Inorg Chem 51:10675-10687

49. Basu S, Naidu BS, Viswanadh B, Sudarsan V, Jha SN, Bhattacharyya D, Vatsa RK (2014) Nature of $\mathrm{WO}_{4}$ tetrahedra in blue light emitting $\mathrm{CaWO}_{4}$ probed through the EXAFS technique. RSC Adv 4:15606-15612

50. Kuzmin A, Purans J (2001) Local atomic and electronic structure of tungsten ions in $\mathrm{AWO}_{4}$ crystals of scheelite and wolframite types. Radiat Meas 33:583-586

51. Poirier GL, Cassanjes FC, Messaddeq Y, Ribeiro SJL, Michalowicz A, Poulain M (2005) Local order around tungsten atoms in tungstate fluorophosphates glasses by X-ray absorption spectroscopy. J Non-Cryst Solids 351:3644-3648

52. Montanari B, Barbosa AJ, Ribeiro SJL, Messaddeq Y, Poirier G, Li MS (2008) Structural study of thin films prepared from 
tungstate glass matrix by Raman and X-ray absorption spectroscopy. Appl Surf Sci 254:5552-5556

53. http://www.sigmaplot.com/products/peakfit/peakfit.php

54. Daviero-Minaud S, Rolle A, Kongmark C, Vannier RN (2009) Local environment in $\mathrm{Ba}_{2} \mathrm{In}_{2-x} \mathrm{~W}_{x} \mathrm{O}_{5+3 x / 2}$ oxide ion conductors. J Solid State Chem 182:289-294

55. Ko JYP, Hu Y, Armelao L, Sham TK (1990) XANES and XEOL studies of Eudoped calcium tungstate in silica synthesized by solgel method. J Phys 190:012078-012081

56. Gonçalves RF, Cavalcante LS, Nogueira IC, Longo E, Godinho MJ, Sczancoski JC, Mastelaro VR, Pinatti IM, Rosa ILV, Marques APA (2015) Rietveld refinement, cluster modelling, growth mechanism and photoluminescence properties of $\mathrm{CaWO}_{4}: \mathrm{Eu}^{3+}$ microcrystals. CrystEngComm 17:1654-1666

57. Porto SP, Scott JF (1967) Raman spectra of $\mathrm{CaWO}_{4}, \mathrm{SrWO}_{4}$, $\mathrm{CaMoO}_{4}$, and $\mathrm{SrMoO}_{4}$. Phys Rev 157:716-719

58. Wannapop S, Thongtem T, Thongtem S (2011) Characterization of $\mathrm{SrWO}_{4}$-PVAand $\mathrm{SrWO}_{4}$ spiders' webs synthesized by electrospinning. Ceram Inter 37:3499-3507

59. Degreniers S, Jandl S, Carlone C (1984) Temperature dependence of the Raman active phonons in $\mathrm{CaWO}_{4}, \mathrm{SrWO}_{4}$ and $\mathrm{BaWO}_{4}$. J Phys Chem Solids 45:1105-1109

60. Golubović A, Gajić R, Dohčević-Mitrović Z, Nikolić S (2006) Nd induced changes in IR spectra of $\mathrm{CaWO}_{4}$ single crystals. J Alloys Compd 415:16-22

61. Gong Q, Qian X, Ma X, Zhu Z (2006) Large-scale fabrication of novel hierarchical 3D $\mathrm{CaMoO}_{4}$ and $\mathrm{SrMoO}_{4}$ mesocrystals via a microemulsion-mediated route. Cryst Growth Des 6:1821-1825

62. Yin Y, Yang F, Yang Y, Gan Z, Qin Z, Gao S, Zhou B, Li X (2011) Controlled synthesis of $\mathrm{BaWO}_{4}$ hierarchical nanostructures by exploiting oriented attachment in the solution of $\mathrm{H}_{2} \mathrm{O}$ and $\mathrm{C}_{2} \mathrm{H}_{5} \mathrm{OH}$. Superlatt Microstruct 49:599-607
63. Tian Y, Chen B, Yu H, Hua R, Li X, Sun J, Cheng L, Zhong H, Zhang J, Zheng Y, Yu T, Huang L (2011) Controllable synthesis and luminescent properties of three-dimensional nanostructured $\mathrm{CaWO}_{4}: \mathrm{Tb}^{3+}$ microspheres. J Colloid Interface Sci 360:586-592

64. Kubelka P, Munk F (1931) Ein Beitrag zur optik der farbanstriche. Zeit Für Tech Physik 12:593-601

65. Morales AE, Mora ES (2007) Use of diffuse reflectance spectroscopy for optical characterization of un-supported nanostructures. U Pal Rev Mex Fis S 53:18-22

66. Smith RA (1978) Semiconductors, 2nd edn. Cambridge University Press, London

67. Zhang Y, Holzwarth NAW, Williams RT (1998) Electronic band structures of the scheelite materials $\mathrm{CaMoO}_{4}, \mathrm{CaWO}_{4}, \mathrm{PbMoO}_{4}$, and $\mathrm{PbWO}_{4}$. Phys Rev B 57:12738-12750

68. Lacomba-Perales R, Ruiz-Fuertes J, Errandonea D, MartínezGarcía D, Segura A (2008) Optical absorption of divalent metal tungstates: correlation between the band-gap energy and the cation ionic radius. Eur Phys Lett 83:37002-37006

69. Longo VM, Orhan E, Cavalcante LS, Porto SL, Espinosa JWM, Varela JA, Longo E (2007) Understanding the origin of photoluminescence in disordered $\mathrm{Ca}_{0.60} \mathrm{Sr}_{0.40} \mathrm{WO}_{4}$ : an experimental and first-principles study. Chem Phys 334:180-188

70. Tian G, Sheng N, Qiu X (2014) Structure and photoluminescence properties of $\mathrm{SrWO}_{4} 3 \mathrm{D}$ microspheres synthesized by the surfactant-assisted hydrothermal method. Cryst Res Technol 49:360-365

71. Ling CS (2014) Cyclic Microwave-assisted metathetic synthesis and spectroscopic properties of SPION/SrWO4:Er3+, Yb3+ composites. Asian J Chem 26:1848-1852

72. Sun X, Sun X, Li X, He J, Wang B (2014) Molten salt synthesis, characterization, and luminescence of $\mathrm{SrWO}_{4}, \mathrm{SrWO}_{4}: \mathrm{Tb}^{3+}$ and $\mathrm{SrWO}_{4}: \mathrm{Eu}^{3+}$ powders. J Mater Sci 25:2320-2324 